\title{
Unraveling the chemical composition, antioxidant, $\alpha$-amylase and $\alpha$-glucosidase inhibition of Moroccan propolis
}

\author{
Hassan Laaroussi $^{\mathrm{a}}$, Pedro Ferreira-Santos ${ }^{\mathrm{b}}$, Zlatina Genisheva ${ }^{\mathrm{b}}$, Meryem Bakour ${ }^{\mathrm{a}}$, \\ Driss Ousaaid ${ }^{\mathrm{a}}$, José Antonio Teixeira ${ }^{\mathrm{b}}$, Badiaa Lyoussi ${ }^{\mathrm{a}, *}$ \\ ${ }^{a}$ Laboratory of Natural Substances, Pharmacology, Environment, Modeling, Health and Quality of Life (SNAMOPEQ), Department of Biology, Faculty of Sciences Dhar \\ Mehraz, Sidi Mohamed Ben Abdellah University, 30000, Fez, Morocco \\ ${ }^{\mathrm{b}}$ CEB - Centre of Biological Engineering, University of Minho, Campus de Gualtar, 4710-057, Braga, Portugal
}

\section{A R T I C L E I N F O}

\section{Keywords:}

Propolis quality

Phenolic compounds

Physicochemical analysis

Antioxidant activity

Geographical origin

$\alpha$-amylase and $\alpha$-glucosidase inhibitory

activities

\begin{abstract}
A B S T R A C T
In the present study, seven propolis samples collected from different areas of Morocco were evaluated for various potential attributes. Physicochemical parameters (moisture, $\mathrm{pH}$, soluble substance, insoluble substance, ash content, conductivity, organic matter, resin, balsams, total carbohydrates, total proteins and mineral content), structural characterization by FTIR, phenolic and flavonoid composition and some biological activities (antioxidant, and $\alpha$-glucosidase and $\alpha$-amylase inhibitory activities) were determined. The analyzed physicochemical parameters showed the following values: moisture (3.3-5.2\%), pH (4.1-5.5), soluble substance (66.1-75.4\%), insoluble substance $(23.8-33.7 \%)$, ashes $(1.6-2.3 \%)$, conductivity $(1.5-2.5 \mathrm{mS} / \mathrm{cm})$, organic matter (97.70-98.4\%), wax (19.7-51.5\%), resin (46.8-75.2\%), balsam (1.5-3.1\%), total carbohydrates (1.5-2.0 mg Glceq/g), and total proteins (1.7-6.2 g/100 g). Calcium, sodium, potassium, and magnesium were the most predominant minerals present in propolis samples. The phytochemical composition indicated the presence of phenolic acids, flavonoids and stilbens compounds described as having a high antioxidant capacity and potential $\alpha$-amylase $\left(\mathrm{IC}_{50}=195.09-963.79 \mu \mathrm{g} / \mathrm{mL}\right.$ ) and $\alpha$-glucosidase $\left(\mathrm{IC}_{50}=90.99-876.24 \mu \mathrm{g} / \mathrm{mL}\right.$ ) inhibitory activities. Moreover, FTIR spectra showed that the samples are structurally different between them, validating the results of the physicochemical analysis. The outcome of this study provides relevant information about Moroccan propolis composition and quality standards.
\end{abstract}

\section{Introduction}

Natural products are inexhaustible sources of bioactive molecules, and nowadays they have been extensively exploited by the pharmaceutical industries (Cseke et al., 2016). Propolis is a lipophilic resinous natural material produced by honeybees from different exudates and plant buds mixed with wax, pollen, and its hypo-pharyngeal secretions. The word propolis is derived from Greek (pro = defense and polis $=$ the city) which means defense of the beehive. It is considered as an internal immunity of the hive by ensuring its protection against many intruders and weather conditions (Pobiega, Kraśniewska, \& Gniewosz, 2019). It is a popular bee product extensively used in bio-cosmetics and folk medicine for the prevention and self-treatment of several diseases and has become the objective of many scientific investigations. Different biological and pharmacological effects have been referred to the propolis extracts, including, antioxidant, antibacterial, antitumoral, antiviral activities, and anti-hyperglycemic effect (Anjum et al., 2019; Cheng, Zhang, \& Hu, 2017). The chemical composition of propolis is extremely complex and varied worldwide. Actually, more than 420 compounds were identified in propolis samples from various geographical locations (Milojković Opsenica et al., 2016), such as polyphenols: particularly cinnamic and benzoic acids; and their derivatives, aliphatic hydrocarbons, amino acids, sugars, vitamin and minerals (Anjum et al., 2019). The quantitative and the qualitative composition of propolis depend on several factors including, harvest season, predominant plant source, and pedoclimatic conditions of areas where hives were located (Valencia et al., 2012). Furthermore, the physicochemical characterization and the identification of bioactive ingredients of propolis by validated methods are crucial approaches for its standardization and quality control for possible industrial applications (Bankova et al., 2019; Escriche \& Juan-Borrás, 2018; Popova et al., 2004).

In this context, and in order to understand the influence of

\footnotetext{
* Corresponding author.

E-mail address: lyoussi@gmail.com (B. Lyoussi).
} 
predominant local plant source and geographical conditions on the phytochemical composition of propolis samples and their impact on the functional potential of propolis extracts, the current research was designed. Seven propolis samples harvested from different geographical locations of Morocco were studied for their physicochemical composition, antioxidant, $\alpha$-amylase, and $\alpha$-glucosidase inhibitory activities.

\section{Materials and methods}

\subsection{Chemicals}

Aluminum chloride $\left(\mathrm{AlCl}_{3}\right)$, Folin-Ciocalteu reagent, 2,2'-Azino-bis (3-ethylbenzothiazoline-6-sulfonic acid) diammonium salt (ABTS), 2,2Di(4-tert-octylphenyl)-1-picrylhydrazyl (DPPH), 6-hydroxy-2,5,7,8-tetramethylchroman-2-carboxylic acid (Trolox), acarbose, ferrous sulphate $\left(\mathrm{FeSO}_{4}\right)$, sodium nitrite $\left(\mathrm{NaNO}_{2}\right)$, sodium sulphate $\left(\mathrm{Na}_{2} \mathrm{SO}_{4}\right)$, sodium carbonate $\left(\mathrm{Na}_{2} \mathrm{CO}_{3}\right)$, sodium hydroxide $(\mathrm{NaOH})$, phenol reagent, Bradford reagent, 2,4,6-Tris(2-pyridyl)-s-triazine (TPTZ), nitric acid, glucose, Bovine serum albumin (BSA), porcine pancreatic (EC 3.2.1.1, type VI), saccharomyces cerevisiae $\alpha$-glucosidase (EC 3.2.1.20, type I), $p$-nitrophenyl-R- $d$-glucopyranoside (pNPG), glucose and all HPLC standard markers (catechin, epicatechin, vanilic acid, o-coumaric acid, ferulic acid, ellagic acid, naringin, hesperidin, apigenin, cinnamic acid, resveratrol, rosmarinic acid, rutin, chlorogenic acid, quercetin, and kaempferol) were obtained from Sigma-Aldrich (St. Louis, MO, USA). All other chemicals used were of analytical grade and water was ultra-pure.

\subsection{Propolis samples and extracts preparation}

Seven raw propolis samples were collected between the first of May and mid-June 2018 from modern and healthy hives installed in different geographical locations of Morocco (Fig. 1 and Table 1). The hives are free from any pesticides, mites, and pathogens. One gram of each propolis sample was macerated in $30 \mathrm{ml}$ of ethanol $(70 \%, \mathrm{v} / \mathrm{v})$ under mechanical stirring for one week in the dark at room temperature. The final extracts were filtered (Whatman, $n^{\circ} 1$ ), and the supernatant was collected for in vitro tests. A yield of $44.56 \pm 4.18 \%$ was obtained.

The extractions were performed in triplicate.

\subsection{Physicochemical and elementary analysis of propolis samples}

2.3.1. Moisture, soluble solids, insoluble solids, $p H$, organic material and electrical conductivity

The moisture, the soluble and the insoluble solids were determined according to the standard method AOAC, $14^{\text {th }}$ Ed (Williams, 1984).

For the moisture, according to the AOAC method ( $\left.{ }^{\circ} 52.729\right), 3 \mathrm{~g}$ of propolis were placed in the oven for $1 \mathrm{~h}$ at $105^{\circ} \mathrm{C}$; the weight was taken three times after their stabilization in the desiccators. The moisture was calculated using the following equation:

Moisture $(\%)=\frac{(\mathrm{W} 1-\mathrm{W} 2)}{\mathrm{W} 1} \times 100$

where: $\mathrm{W} 1=$ weight of sample; $\mathrm{W} 2=$ weight of the dried sample.

For soluble and insoluble solids (AOAC method $\mathrm{n}^{\circ}$ 945.79), $250 \mathrm{~mL}$ of ethanol was added to $3 \mathrm{~g}$ of propolis, and the mixture was automatically stirred for $30 \mathrm{~min}$. After filtration, the percentages of soluble and

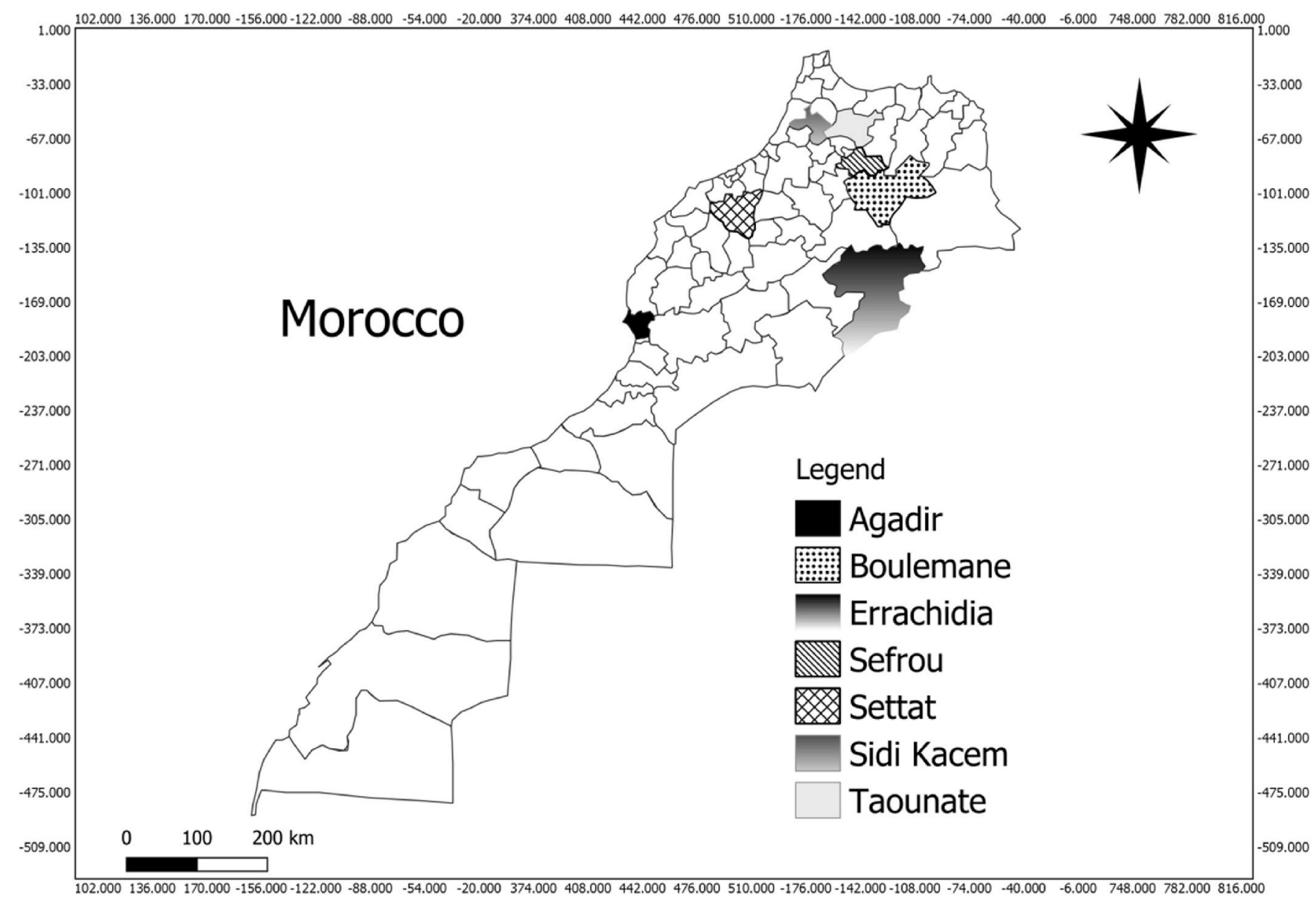

Fig. 1. Map of Morocco regions showing propolis sample location 
Table 1

Geographical characteristics and predominant plant species of harvesting areas.

\begin{tabular}{|c|c|c|c|c|c|c|c|}
\hline Samples & $\begin{array}{l}\text { Locality } \\
\text { name }\end{array}$ & Latitude (N) & $\begin{array}{l}\text { Longitude } \\
\text { (W) }\end{array}$ & $\begin{array}{l}\text { Altitude } \\
(\mathrm{m})\end{array}$ & $\begin{array}{l}\text { Pluviometry } \\
(\mathrm{mm})\end{array}$ & $\begin{array}{l}\text { Temperature } \\
\left({ }^{\circ} \mathrm{C}\right)\end{array}$ & Surrounding plant species \\
\hline S1 & Boulemane & $33^{\circ} 21^{\prime} 46.3^{\prime \prime}$ & $4^{\circ} 43^{\prime} 48.3^{\prime \prime}$ & 1752 & $9-60$ & $3.2-22.1$ & $\begin{array}{l}\text { Rosmarinus officinalis L, Thymus vulgarisL, Pinus halepensis Mill, } \\
\text { Globularia alypum L, Juniperus oxycedrus L, Cistus ladanifer L, } \\
\text { Lavandula angustifolia Mill and Bupleurum spinosum Gouan }\end{array}$ \\
\hline S2 & Sefrou & $33^{\circ} 49^{\prime} 49.89^{\prime \prime}$ & $4^{\circ} 50^{\prime} 7.14^{\prime \prime}$ & 823 & $2.4-62.7$ & $9.2-26.3$ & $\begin{array}{l}\text { Quercus ilex L, Juniperus thurifera L, Pinus halepensis Mill, } \\
\text { Rosmarinus officinalis L, Cistus ladanifer L, Lavandula angustifolia } \\
\text { Mill, and Pistacia lentiscus L }\end{array}$ \\
\hline S3 & Taounate & $34^{\circ} 32^{\prime} 12.9^{\prime \prime}$ & $4^{\circ} 38^{\prime} 23.53^{\prime \prime}$ & 600 & $1-101$ & $9.1-26.5$ & $\begin{array}{l}\text { Ceratonia siliqua L, Pistacia lentiscus L, Lavandula angustifolia Mill, } \\
\text { Ficus carica L, Rosmarinus officinalis L, Prunus domestica L, Quercus } \\
\text { ilexL, and Pinus halepensis Mill }\end{array}$ \\
\hline S4 & Sidi Kacem & $34^{\circ} 13^{\prime} 33.66$ & $\begin{array}{l}5^{\circ} 42^{\prime} \\
46.49^{\prime \prime}\end{array}$ & 83 & $1-93$ & $12.6-28.5$ & $\begin{array}{l}\text { Eucalyptus globulus Labill, Pinus halepensis Mill, Ceratonia siliqua L, } \\
\text { Juniperus thurifera L, Quercus suber L, Pistacia lentiscus L, and Thuya } \\
\text { occidentalis L }\end{array}$ \\
\hline S5 & Errachidia & $31^{\circ} 55^{\prime} 38.05^{\prime \prime}$ & $4^{\circ} 25^{\prime} 42.59^{\prime \prime}$ & 1039 & $3-20$ & $9.1-31.6$ & $\begin{array}{l}\text { Ficus carica L, Rosmarinus officinalis L, thymus vulgaris } \mathrm{L} \text {, and } \\
\text { Juniperus thurifera } \mathrm{L}\end{array}$ \\
\hline S6 & Settat & $\begin{array}{l}32^{\circ} 59^{\prime} \\
39.00^{\prime \prime}\end{array}$ & $7^{\circ} 37^{\prime} 24^{\prime \prime}$ & 405 & $1-66$ & $10.4-25.4$ & $\begin{array}{l}\text { Eucalyptus globulus Labill, Quercus suber L, Cedrus atlantica (Manetti } \\
\text { ex Endl), Lavandula angustifolia Mill, Ferula communis L, Cistus } \\
\text { ladanifer L and Tetraclinis articulate (Vahl) Mast }\end{array}$ \\
\hline S7 & Agadir & $\begin{array}{l}30^{\circ} 25^{\prime} \\
39.91^{\prime \prime}\end{array}$ & $9_{\prime \prime}^{\circ} 35^{\prime} 53.18$ & 31 & $0-52$ & $13.9-22.6$ & Euphorbia resinifera berg, Argania spinosa $\mathrm{L}$ \\
\hline
\end{tabular}

insoluble solids were determined by applying the following equations:

Solublesolids : $S S(\%)=\frac{(S W-I W)}{S W} \times 100$

Insolublesolids : IS $(\%)=\frac{I W}{S W} \times 100$

where SW = sample weight, IW = insoluble weight.

The $\mathrm{pH}$ of the hydro-ethanolic propolis solution $10 \%(\mathrm{w} / \mathrm{v})$ was determined using a $\mathrm{pH}$ apparatus. The ash content was determined according to the protocol described by (Bogdanov, Martin, \& Lullmann, 2002). Briefly, after preliminary ashing of propolis sample at $500{ }^{\circ} \mathrm{C}$ for $4 \mathrm{~h}$, the ash content was measured. The residue was then weighed 3 times. The ash (\%) was determined as follow:

$\operatorname{Ash}(\%)=\frac{\mathrm{mA}}{\mathrm{mP}} \times 100$

where $\mathrm{mA}=$ the net mass of the ashes, and $\mathrm{mP}=$ the gross mass of propolis.

The amount of organic material was calculated by the following equation:

Organic materical $(\%)=100-$ Ash content $(\%)$

Electrical conductivity was measured on a hydro-ethanolic propolis solution, $20 \%(\mathrm{w} / \mathrm{v})$. The results are expressed as milliSiemens per centimeter (mS/cm) (Bogdanov et al., 2002). All physicochemical tests were made in triplicate.

\subsubsection{Wax, balsam, and resin quantifications}

The amount of wax, balsam, and resin was determined following the method described by (Touzani et al., 2018). Briefly, for the wax: $120 \mathrm{~mL}$ of petroleum ether were added to $3 \mathrm{~g}$ of crude propolis. Then the mixture was put in a Soxhlet extractor for $6 \mathrm{~h}$ at $50{ }^{\circ} \mathrm{C}$. The extract was placed in an evaporator flask after weight stabilization in the desiccator and 120 $\mathrm{ml}$ of $70 \%$ ethanol were added and mixed until a clear solution was obtained. Then, the solution was allowed to cool at $0{ }^{\circ} \mathrm{C}$ for $1 \mathrm{~h}$. After filtration with Whatman $\mathrm{n}^{\circ} 1$ filter (previously weighed), both, filter paper and flask were dried at $110{ }^{\circ} \mathrm{C}$ for $1 \mathrm{~h}$ and weighed after their stabilization in a desiccator. The residue weight represents the wax content. The results are presented as $\% \mathrm{w} / \mathrm{w}$.

For Balsam: After wax extraction, the obtained filtrate was concentrated in a rotary evaporator at $60{ }^{\circ} \mathrm{C}$. After that, $50 \mathrm{~mL}$ of dichloromethane was added to the aqueous residue. The mixture was put under mechanical stirring; the organic phase was recovered and filtered in a previously weighed evaporator flask, and dried over $30 \mathrm{~g}$ of anhydrous $\mathrm{Na}_{2} \mathrm{SO}_{4}$. The solution was evaporated at $60{ }^{\circ} \mathrm{C}$; the flask weight was taken 3 times after its stabilization in the desiccators. The results are expressed as \% $\mathrm{w} / \mathrm{w}$.

For Resin: The residual propolis obtained after the wax extraction was mixed with120 mL of chloroform/ethanol 1:1 (v/v) and placed in a Soxhlet extractor. After $6 \mathrm{~h}$, the extract was transferred to an evaporator flask (previously weighed) and concentrated at $70{ }^{\circ} \mathrm{C}$. The flask was weighed 3 times after drying in the oven for $1 \mathrm{~h}$ at $110^{\circ} \mathrm{C}$. The results are expressed as \% $\mathrm{w} / \mathrm{w}$.

\subsection{Total proteins quantification (TP)}

The protein content of propolis was estimated by quantification of total nitrogen after sample acid digestion using a Kjeldahl digestor (Tecator, FOSS, Denmark), applying the nitrogen conversion factor ( $\mathrm{N}$ $\times$ 6.25) (Ferreira-Santos, Nunes, et al., 2020).

\subsection{Determination of mineral elements}

Mineral elements were determined as described previously by (Laaroussi, Bouddine, Bakour, Ousaaid, \& Lyoussi, 2020) using the calcination method (ICP-AES). Briefly, $5 \mathrm{~mL}$ of nitric acid (100 mM) was mixed with propolis ashes. After the total evaporation of the nitric acid, more $10 \mathrm{~mL}$ of the same acid was slowly added and the final mixture was made up to $25 \mathrm{~mL}$ with ultra-pure water. Mineral elements were determined using an air/acetylene flame, and the quantitative determination was carried out after calibrating the instrument using different concentrations of $\mathrm{Ca}, \mathrm{Na}, \mathrm{K}, \mathrm{Mg}, \mathrm{Cu}, \mathrm{Zn}, \mathrm{Ni}, \mathrm{Pb}$, and $\mathrm{Cd}$ dissolved in $0.1 \%$ lanthanum. The results were expressed in $\mathrm{mg}$ of mineral per kilogram of propolis $(\mathrm{mg} / \mathrm{Kg})$. All samples were analyzed in triplicate.

\subsection{ATR-fourier transform infrared spectroscopy}

Functional groups and bonding arrangement of constituents present in the raw propolis samples were determined by Fourier Transform Infrared Spectroscopy (FTIR) using an ALPHA II- Bruker spectrometer (Ettlingen, Germany) with a diamond-composite attenuated total reflectance (ATR) cell. The FTIR spectra were recorded in the range of $4000-400 \mathrm{~cm}^{-1}$, with 24 scan cycles per sample at a resolution of $4 \mathrm{~cm}^{-1}$ (Ferreira-Santos, Genisheva, et al., 2020). 
2.7. Phytochemical constituents, antioxidant, $\alpha$-amylase and $\alpha$-glucosidase inhibitory activities of propolis extracts

\subsubsection{Total phenolic content (TPC)}

The TPC was determined by the method of Folin-Ciocalteu described by (Ferreira-Santos, Genisheva, Pereira, Teixeira, \& Rocha, 2019). Briefly, $60 \mu \mathrm{L}$ of Folin-Ciocalteu reagent and $15 \mu \mathrm{L}$ of sodium carbonate solution $(75 \mathrm{~g} / \mathrm{L})$ were added to $5 \mu \mathrm{L}$ of propolis hydro-ethanolic extract. The concentration of the coloration produced was measured at $700 \mathrm{~nm}$ by an UV/Vis spectrophotometer (Synergy HT, BioTek Instruments, Inc., U.S.A.) after incubating the mixture for $5 \mathrm{~min}$ at $60{ }^{\circ} \mathrm{C}$. Gallic acid $(0-500 \mathrm{mg} / \mathrm{L})$ was used as a standard to achieve the calibration curve $\left(\mathrm{R}^{2}=0.996\right)$ and the results were expressed in mg gallic acid equivalent (GAE) per gram of propolis (mg GAE/g).

\subsubsection{Total flavonoids content (TFC)}

Total flavonoids were determined following the procedure described by (Ferreira-Santos, Genisheva, et al., 2020). One hundred microliters of ethanolic extract of propolis were mixed with sodium nitrite (5\%) and $150 \mu \mathrm{L}$ of $\mathrm{AlCl}_{3}$ solution (10\%). After $6 \mathrm{~min}, 200 \mu \mathrm{L}$ of $\mathrm{NaOH}$ solution (1\%) was added and the mixture was properly mixed and allowed to stand in the dark for $60 \mathrm{~min}$. The absorbance was measured at $510 \mathrm{~nm}$. Quercetin (2.6-142 mg/L) was used to perform the standard curve $\left(\mathrm{R}^{2}\right.$ $=0.997$ ) and the results were expressed in milligram of quercetin equivalent $(\mathrm{QE})$ per gram of propolis (mg QE/g).

\subsubsection{Total carbohydrates (TC)}

TC content was determined using the phenol-sulfuric acid method described (Ferreira-Santos, Nunes, et al., 2020). For this, $50 \mu \mathrm{L}$ of the sample was mixed with $150 \mu \mathrm{L}$ of sulfuric acid (96-98\% (v/v)). Then, 30 $\mu \mathrm{L}$ of phenol reagent $(5 \%)$ was added and the final solution was heated for $5 \mathrm{~min}$ at $90{ }^{\circ} \mathrm{C}$. The absorbance was measured at $490 \mathrm{~nm}$ by microplate reader after cooling down at room temperature for $5 \mathrm{~min}$. Glucose $(10-600 \mathrm{mg} / \mathrm{L})$ was used as a standard to achieve the calibration curve $\left(\mathrm{R}^{2}=0.992\right)$. The total carbohydrates content was expressed as a milligram of glucose equivalents (GlcE) per $g$ of propolis (mg GLcE/g).

\subsubsection{Soluble protein content}

The soluble protein content was analyzed using the Bradford assay with some modifications (Bradford, 1976). For this, a subsample of 20 $\mu \mathrm{L}$ propolis extract was mixed with $230 \mu \mathrm{L}$ of Bradford dye reagent. The microplate was placed in the dark for $5 \mathrm{~min}$ and the absorbance was measured at a wavelength of $595 \mathrm{~nm}$ by an UV/Vis spectrophotometer (Synergy HT, BioTek Instruments, Inc., U.S.A.). Bovine albumin serum (BSA) was used to perform the standard curve (33-1000 mg/L, $\mathrm{R}^{2}=$ 0.989 ) and the results were expressed as milligram of BSA equivalents per gram of propolis (mg BSA/g).

\subsubsection{Antioxidant activity of propolis extracts}

2.7.5.1. Radical cation decolorization (ABTS assay). The ABTS assay of propolis extracts was determined as follows: $200 \mu \mathrm{L}$ of 2,2'-azino-bis(3ethylbenzothiazoline-6-sulfonic acid) diammonium salt (ABTS) radical cation solution was mixed with $10 \mu \mathrm{L}$ of different dilutions of each propolis extract. The resulting solutions were incubated in the dark for $30 \mathrm{~min}$ at room temperature and the intensity of produced coloration was measured immediately at $734 \mathrm{~nm}$ by UV/Vis spectrophotometer. Ethanol $70 \%$ was used as a control solution instead of the sample. A standard solution of Trolox was used as a positive control. The ABTS radical cation inhibition percent was determined using equation (6) (Ferreira-Santos et al., 2019). The IC $_{50}$ results were expressed in $(\mu \mathrm{g} / \mathrm{mL})$.

$\%$ inhibition $=\frac{\text { Abs control }- \text { Abs sample }}{\text { Abs control }} \times 100$
2.7.5.2. Free radical scavenging activity (DPPH assay). Two hundred and seventy $\mu \mathrm{L}$ of 2,2-diphenyl-1-picryl-hydrazyl-hydrate (DPPH) solution $(150 \mu \mathrm{M}$, prepared in methanol with an absorbance of $0.700 \pm 0.01$ at $515 \mathrm{~nm}$ ) was added to $30 \mu \mathrm{l}$ of different dilutions of each propolis extract (Ferreira-Santos et al., 2019). Then, the mixture reactions were incubated in the dark during $1 \mathrm{~h}$ at room temperature. The absorbance was measured at $515 \mathrm{~nm}$ and the antiradical activity (\% inhibition) was calculated using equation (6). DPPH inhibition concentration at $50 \%$ $\left(\mathrm{IC}_{50}\right)$ is determined using six different dilutions of each sample, considering that the percent inhibition had to be between $20 \%$ and $80 \%$, and the results were expressed in microgram of propolis extract per $\mathrm{mL}$ $(\mu \mathrm{g} / \mathrm{mL})$. Ethanol $70 \%$ was used as control solution instead of the sample, and a standard solution of 6-hydroxy-2,5,7,8-tetramethylchroman-2-carboxylic acid (Trolox) was used as a positive control.

2.7.5.3. Ferric reducing antioxidant power (FRAP assay). Two hundred ninety $\mu \mathrm{L}$ of FRAP reagent was mixed with a $10 \mu \mathrm{L}$ aliquot of propolis sample the absorbance was determined at $593 \mathrm{~nm}$ after the incubation of the reaction mixture in the dark at $37{ }^{\circ} \mathrm{C}$ for $15 \mathrm{~min}$ (Ferreira-Santos et al., 2019). Aqueous solution of ferrous sulphate $\mathrm{FeSO}_{4} \cdot 7 \mathrm{H}_{2} \mathrm{O}$ $(1000-100 \mu \mathrm{M})$ was used for standard curve preparation $(\mathrm{R} 2=0.993)$. The FRAP values are expressed as micromoles of ferrous equivalent per $g$ of propolis $(\mu \mathrm{mol} \mathrm{Fe} 2+/ \mathrm{g})$.

2.7.6. $\alpha$-amylase and $\alpha$-glucosidase inhibitory activities of propolis extracts $\alpha$-amylase and $\alpha$-glucosidase inhibition assays were determined as described previously by (Ferreira-Santos, Genisheva, et al., 2020). For $\alpha$-amylase inhibition assay, $500 \mu \mathrm{L}$ of $\alpha$-amylase solution $(0.5 \mathrm{mg} / \mathrm{mL})$ was incubated with $500 \mu \mathrm{L}$ of different concentrations of each propolis extract at $37{ }^{\circ} \mathrm{C}$ for $15 \mathrm{~min}$. Ethanol $70 \%$ and acarbose were used as a negative and positive control, respectively. Afterward, $500 \mu \mathrm{L}$ of starch solution (1\%) was added and the mixture was incubated for $15 \mathrm{~min}$ at $37{ }^{\circ} \mathrm{C}$. Immediately, $1 \mathrm{~mL}$ of dinitrosalicylic acid color reagent was added to the reaction and placed $10 \mathrm{~min}$ in a boiling water bath. The final mixture was diluted 10 times and the absorbance of each dilution was read at $540 \mathrm{~nm}$.

Concerning $\alpha$-glucosidase inhibition assay, a mixture of different propolis concentrations and $p$-nitrophenyl-R-d-glucopyranoside (pNPG, $3 \mathrm{mM}$ ) was added to the $\alpha$-glucosidase solution $(10 \mathrm{U} / \mathrm{mL})$ then, the mixture was incubated for $15 \mathrm{~min}$ at $37^{\circ} \mathrm{C}$, and the reaction was stopped by adding $\mathrm{Na}_{2} \mathrm{CO}_{3}$ solution $(1 \mathrm{M})$. The intensity of $p$-nitrophenol coloration produced was measured at $400 \mathrm{~nm}$.

$\alpha$-amylase and $\alpha$-glucosidase inhibitory activities (\%) were calculated using equation (2). The propolis concentration required to inhibit $50 \%\left(\mathrm{IC}_{50}\right)$ of $\alpha$-amylase and $\alpha$-glucosidase activity was calculated from a dose-response curve, and the results were expressed in $(\mu \mathrm{g} / \mathrm{mL})$.

\subsection{Identification and quantification of phenolic compounds by UHPLC}

Ethanolic extracts of propolis samples were analyzed using a Shimatzu Nexpera X2 UPLC chromatograph equipped with Diode Array Detector (DAD) (Shimadzu, SPD-M20A) following the method described by (Ferreira-Santos et al., 2019). Separation was performed on a reversed-phase Aquity UPLC BEH C18 column $(2.1 \mathrm{~mm} \times 100 \mathrm{~mm}, 1.7$ $\mu \mathrm{m}$ particle size; from Waters) and a precolumn of the same material at $40{ }^{\circ} \mathrm{C}$. The flow rate was $0.4 \mathrm{~mL} / \mathrm{min}$. HPLC grade solvents water/formic acid $0.1 \%$ (A) and acetonitrile (B) were used. The elution gradient for solvent B was as follows: from 0.0 to 5.5 min eluent B at $5 \%$, from 5.5 to 17 min linearly increasing from 5 to $60 \%$, from 17.0 to $18.5 \mathrm{~min}$ a linearly increasing from 60 to $100 \%$; the column was equilibrated at $5 \%$ from 18.5 to $30.0 \mathrm{~min}$. Phenolic compounds were identified by comparing their UV spectra and retention times with that of corresponding standards. Quantification was carried out using calibration curves for each compound analyzed using concentrations between 250 and $2.5 \mathrm{mg} / \mathrm{L}$. In all cases, the coefficient of linear correlation was $\mathrm{R}^{2}>$ 
0.99. Compounds were quantified and identified at different wavelengths (209-370 nm). The values of individual phenolic compounds were expressed in milligrams per kilogram of propolis $(\mathrm{mg} / \mathrm{Kg})$. All analyses were made in triplicate.

\subsection{Statistical analysis}

The extraction and analyses were performed in triplicate and the data are presented as mean \pm standard deviation (SD) values. GraphPad Prism software (version 6.0; GraphPad Software, Inc., San Diego, CA, U. S.A.) was used for statistical analyses. The analysis of variance (ANOVA) and the least significant difference test was used to determine statistically different values at a significance level of $p<0.05$. Principal component analysis (PCA) was made using the R software (version 3.6.2, Vienna, Austria).

\section{Results and discussion}

\subsection{Physicochemical analysis of propolis}

Physicochemical proprieties, essential parameters on the standardization and the evaluation of propolis quality, are summarized in (Table 2). The recorded moisture in our propolis samples ranged between $3.30 \pm 0.17$ and $5.16 \pm 0.20 \%$, which are in the range of Portuguese propolis that shows values between $2.0 \pm 0.0$ and $13.6 \pm 0.3 \%$ (Falcão, 2013). The results are in accordance with the standard norms cited by (Bankova et al., 2019) that fixed the max limit of water content at $8 \%$, and that is an indicator of propolis quality. The water content is affected by beekeeping techniques and storage conditioning (Falcão, Freire, \& Vilas-Boas, 2013). In fact, this wide variation of moisture content may be related to the climatic conditions of each harvesting station (see Table 1).

The $\mathrm{pH}$ values are between $4.11 \pm 0.17$ and $5.10 \pm 0.18$, with the lowest value referred to the station of Sefrou (S2) and the highest value to the station of Errachidia (S5). Our results are in agreement with the data of (Dias, Pereira, \& Estevinho, 2012) concerning propolis samples collected from different areas in Portugal (4.7-5.3) which confirms the acid character of propolis. The acidity of propolis is probably related to its richness on aliphatic and aromatic acids, which strongly depend on the plant source and geographical conditions (Silici, Ünlü, \& Vardar-Ünlü, 2007).

Regarding soluble and insoluble substance, our values are in the range of $66.05 \pm 0.47$ to $75.39 \pm 2.5 \%$ and $23.82 \pm 1.72$ to $33.68 \pm$ $3.10 \%$, respectively. Boulemane sample (S1) has the lower content of soluble substance and higher content in insoluble substance. Agadir station (S7) has the higher content in soluble substance and lower content in insoluble substance. This wide variability confirms the heterogeneity between the analyzed samples. These results go on hand with the finding of (Dias et al., 2012), where the soluble substance varied from $66.0 \pm 4.1$ to $71.1 \pm 2.2 \%$ and the insoluble substance ranged from $27.0 \pm 1.0$ to $45.1 \pm 2.0 \%$. Ash content is a crucial parameter used to guarantee the propolis quality concerning fraud and unethical practice, by differentiating between the powder of fresh propolis and that of propolis mixed with its extraction residue and adulterated with loam (Woisky \& Salatino, 1998). The ash content is largely depending on the mineral quantitative composition of crude propolis. The amounts of ash content in all examined samples were between $1.55 \pm 0.03 \%$ and $2.29 \pm 0.10 \%$, the highest value being detected in propolis from Taounate (S3). The ashes in all studied samples were less than the maximum limit of $5 \%$ cited by (Bankova et al., 2019). This strong difference is largely depending on the soil composition of each propolis source (Regnier, Salatino, \& Luiza, 2020). The organic matter is inversely correlated to the ash content and ranges between $97.70 \pm 0.10 \%$ in propolis from Taounate (S3) to $98.44 \pm 0.03 \%$ in propolis from Boulemane (S1).

Electrical conductivity is the capacity of a matrix to permit the passage of electrical current. It is influenced by the mineral matter and other conductive compounds of propolis. The sample collected from SidiKacem (S4) has the lowest value $(1.21 \pm 0.03 \mathrm{mS} / \mathrm{cm})$, while the highest value of $2.53 \pm 0.1 \mathrm{mS} / \mathrm{cm}$ referred to the sample collected from Taounate (S3).

Regarding resin, wax, and balsam, the results showed that samples with high resin content had low wax content. Propolis samples from Boulemane (S1), SidiKacem (S4), Settat (S6), and Errachidia (S5) expressed the highest amount of resin in comparison with samples from other areas. The lower value of resin corresponds to propolis from Agadir (S7) and the highest value to the sample from Boulemane (S1). These large variations between the studied samples reaffirm the impact of botanical sources in the composition of bee glue.

The low resin proportion in propolis from Agadir (S7) (46.81 \pm $1.76 \%$ ) may be explained by the low availability of collectible resins or by the difficulty of its harvest in this area (Sawaya, da Silva Cunha, \& Marcucci, 2011). Previous reports about different Moroccan propolis showed a strong relationship between the amount of resin, total phenolic content, and antioxidant power (Touzani et al., 2018).

Generally, the results of resin in all propolis samples go on hand with the common criteria and standard norms cited by (Bankova et al., 2019) at a maximum value of $45 \%$. Besides bud plants, wax in the raw propolis comes from its addition by bees during the propolis manufacturing process (Krell, 1996). The proportion of bee wax in propolis depends on its location within the hive as well as on the availability of resin in the area where the hives were located. The amount of wax varied between $19.70 \pm 0.11 \%$ in propolis from Boulemane (S1) and $51.48 \pm 2.40 \%$ in propolis from Agadir (S7).

Table 2

Physicochemical parameters of propolis samples.

\begin{tabular}{|c|c|c|c|c|c|c|c|c|c|c|c|}
\hline Samples & $\begin{array}{l}\text { Moisture } \\
\text { (\%) }\end{array}$ & $\mathrm{pH}$ & $\begin{array}{l}\text { Conductivity } \\
(\mathrm{ms} / \mathrm{cm})\end{array}$ & $\begin{array}{l}\text { Soluble } \\
\text { substance (\%) }\end{array}$ & $\begin{array}{l}\text { Insoluble } \\
\text { substance (\%) }\end{array}$ & Ash (\%) & $\begin{array}{l}\text { Organic } \\
\text { matter (\%) }\end{array}$ & Wax (\%) & Resin (\%) & $\begin{array}{l}\text { Balsams } \\
(\%)\end{array}$ & $\begin{array}{l}\text { Protein } \\
(\%)\end{array}$ \\
\hline S1 & $\begin{array}{l}5.16 \pm \\
0.20^{\mathrm{a}}\end{array}$ & $\begin{array}{l}4.43^{ \pm} \\
0.28^{\mathrm{abc}}\end{array}$ & $2.52 \pm 0.01^{\mathrm{a}}$ & $72.39 \pm 1.69^{\mathrm{a}}$ & $26.44 \pm 1.12^{\mathrm{ab}}$ & $\begin{array}{l}1.55 \pm \\
0.03^{\mathrm{bc}}\end{array}$ & $\begin{array}{l}98.44 \pm \\
0.03^{\mathrm{a}}\end{array}$ & $\begin{array}{l}19.70 \pm \\
0.11^{g}\end{array}$ & $\begin{array}{l}75.19 \pm \\
0.11^{\mathrm{a}}\end{array}$ & $\begin{array}{l}3.10 \pm \\
0.01^{\mathrm{a}}\end{array}$ & $\begin{array}{l}1.65 \pm \\
0.07^{\mathrm{d}}\end{array}$ \\
\hline S2 & $\begin{array}{l}4.86 \pm \\
0.20^{\mathrm{a}}\end{array}$ & $\begin{array}{l}4.11 \pm \\
0.17^{\mathrm{abc}}\end{array}$ & $2.08 \pm 0.03^{b}$ & $\begin{array}{l}66.05 \pm 0.47 \\
\text { abc }\end{array}$ & $33.68 \pm 3.10^{\mathrm{a}}$ & $\begin{array}{l}1.89 \pm \\
0.04^{\mathrm{b}}\end{array}$ & $\begin{array}{l}98.10 \pm \\
0.04^{\mathrm{ab}}\end{array}$ & $\begin{array}{l}36.27 \pm \\
0.14^{c}\end{array}$ & $\begin{array}{l}59.37 \pm \\
0.40^{c}\end{array}$ & $\begin{array}{l}2.21 \pm \\
0.12^{\mathrm{c}}\end{array}$ & $\begin{array}{l}3.91 \pm \\
0.06^{\mathrm{b}}\end{array}$ \\
\hline S3 & $\begin{array}{l}4.26 \pm \\
0.21^{b}\end{array}$ & $\begin{array}{l}5.10 \pm \\
0.18^{\mathrm{a}}\end{array}$ & $2.53 \pm 0.10^{\mathrm{a}}$ & $\begin{array}{l}67.54 \pm 2.18 \\
\mathrm{ab}\end{array}$ & $31.38 \pm 1.48^{\mathrm{a}}$ & $\begin{array}{l}2.29 \pm \\
0.10^{\mathrm{a}}\end{array}$ & $\begin{array}{l}97.70 \pm \\
0.10^{d}\end{array}$ & $\begin{array}{l}39.37 \pm \\
0.42^{\mathrm{b}}\end{array}$ & $\begin{array}{l}52.67 \pm \\
3.08^{c}\end{array}$ & $\begin{array}{l}1.85 \pm \\
0.03^{\mathrm{d}}\end{array}$ & $\begin{array}{l}1.47 \pm \\
0.16^{\mathrm{b}}\end{array}$ \\
\hline S4 & $\begin{array}{l}3.63 \pm 0.15 \\
\mathrm{bc}\end{array}$ & $\begin{array}{l}4.63 \pm \\
0.15^{\mathrm{ab}}\end{array}$ & $1.21 \pm 0.03^{\mathrm{e}}$ & $\begin{array}{l}69.51 \pm 1.20 \\
\mathrm{ab}\end{array}$ & $27.28 \pm 1.66^{\mathrm{ab}}$ & $\begin{array}{l}1.75 \pm \\
0.08^{\mathrm{bc}}\end{array}$ & $\begin{array}{l}98.24 \pm \\
0.08^{\mathrm{a}}\end{array}$ & $\begin{array}{l}24.13 \pm \\
0.37^{\mathrm{e}}\end{array}$ & $\begin{array}{l}72.43 \pm \\
1.61^{\mathrm{a}}\end{array}$ & $\begin{array}{l}1.48 \pm \\
0.03^{\mathrm{e}}\end{array}$ & $\begin{array}{l}6.18 \pm \\
0.03^{\mathrm{a}}\end{array}$ \\
\hline S5 & $\begin{array}{l}3.30 \pm \\
0.17^{\mathrm{bcd}}\end{array}$ & $\begin{array}{l}5.53 \pm \\
0.11^{\mathrm{a}}\end{array}$ & $1.62 \pm 0.02^{\mathrm{c}}$ & $\begin{array}{l}67.69 \pm 3.35 \\
\mathrm{ab}\end{array}$ & $26.79 \pm 3.50^{\mathrm{ab}}$ & $\begin{array}{l}1.82 \pm \\
0.10^{\mathrm{b}}\end{array}$ & $\begin{array}{l}98.18 \pm \\
0.10^{\mathrm{ab}}\end{array}$ & $\begin{array}{l}24.31 \pm \\
0.63^{d}\end{array}$ & $\begin{array}{l}68.90 \pm \\
1.61^{\mathrm{ab}}\end{array}$ & $\begin{array}{l}2.17 \pm \\
0.07^{\mathrm{c}}\end{array}$ & $\begin{array}{l}2.89 \pm \\
0.02^{\mathrm{c}}\end{array}$ \\
\hline S6 & $\begin{array}{l}4.03 \pm \\
0.32^{\mathrm{b}}\end{array}$ & $\begin{array}{l}4.66 \pm \\
0.23^{\mathrm{ab}}\end{array}$ & $2.21 \pm 0.03^{b}$ & $\begin{array}{l}66.01 \pm 1.34 \\
\text { abc }\end{array}$ & $32.40 \pm 1.65^{\mathrm{a}}$ & $\begin{array}{l}2.03 \pm \\
0.09^{\mathrm{b}}\end{array}$ & $\begin{array}{l}97.97 \pm \\
0.09^{\mathrm{abc}}\end{array}$ & $\begin{array}{l}22.02 \pm \\
0.46^{\mathrm{f}}\end{array}$ & $\begin{array}{l}69.40 \pm \\
3.76^{\mathrm{ab}}\end{array}$ & $\begin{array}{l}2.62 \pm \\
0.04^{\mathrm{b}}\end{array}$ & $\begin{array}{l}1.93 \pm \\
0.01^{\mathrm{d}}\end{array}$ \\
\hline S7 & $\begin{array}{l}3.56 \pm 0.05 \\
\text { bc }\end{array}$ & $\begin{array}{l}5.06 \pm \\
0.11^{\mathrm{ab}}\end{array}$ & $1.74 \pm 0.05^{\mathrm{c}}$ & $75.39 \pm 2.5^{\mathrm{a}}$ & $23.82 \pm 1.72^{\mathrm{ab}}$ & $\begin{array}{l}1.62 \pm \\
0.0^{\mathrm{bc}}\end{array}$ & $\begin{array}{l}98.38 \pm \\
0.05^{\mathrm{a}}\end{array}$ & $\begin{array}{l}51.48 \pm \\
2.40^{\mathrm{a}}\end{array}$ & $\begin{array}{l}46.81 \pm \\
1.76^{\mathrm{d}}\end{array}$ & $\begin{array}{l}1.76 \pm \\
0.02^{\mathrm{d}}\end{array}$ & $\begin{array}{l}1.74 \pm \\
0.15^{\mathrm{d}}\end{array}$ \\
\hline
\end{tabular}

Values in the same column followed by the same letter are not significantly different by Tukey's multiple range test $(p<0.05)$. 
For balsams, the result showed a significant difference between the samples. Propolis sample from Boulemane (S1) presented the highest balsam content $(3.10 \pm 0.01 \%)$ and samples from SidiKacem (S4) had the lowest amount $(1.48 \pm 0.03 \%)$. The results obtained are similar to those shown by (Touzani et al., 2018) for seven propolis samples collected from different zones in Morocco.

Total Protein content varied between $1.65 \%$ in (S1) and $6.18 \%$ in (S4) with an average value of $2.82 \%$, which was in agreement with the values reported by (Shehata, Ahmad, Badr, Masry, \& El-Sohaimy, 2020) for propolis from different geographic regions, in which the samples revealed a value of $2.35 \%$ for Brazilian, $2.89 \%$ for Egyptian, $2.24 \%$ for Omani and $2.40 \%$ for Saudi propolis.

The presence of protein in propolis is most probably related to the pollen fraction added by bees in the process of bee glue production.

\subsection{Mineral elements}

The mineral content of the studied propolisis indicated in (Table 3). The results showed that calcium, sodium, potassium, and magnesium are the predominant metals in our samples with average values of $844.15 \pm 337.50,499.01 \pm 270.9,345.30 \pm 139.70$, and $340.97 \pm$ $96.25 \mathrm{mg} / \mathrm{kg}$, respectively. The same main representative minerals were founded in twenty-five propolis samples harvested from different areas of south Spain (Serra Bonvehí \& Orantes-Bermej, 2013). Zinc, copper, and nickel are detected in low amounts with mean values of $10.39 \pm$ $5.99,6.5 \pm 2.12$, and $0.93 \pm 0.39 \mathrm{mg} / \mathrm{kg}$, respectively. Minerals are involved in the regulation of many biochemical processes required for the maintenance of human health (Gupta \& Gupta, 2014). It has been reported that calcium supplementation improves the maintenance of bones, skeletal integrity and prevents osteoporosis (Wimalawansa, Razzaque, \& Al-Daghri, 2018). Magnesium has literally several functioning roles in the human body, from a neurological standpoint; it plays an essential role in neuromuscular conduction and nerve transmission. It is also essential for the regulation of blood pressure, protein production, muscle contraction, and insulin metabolism (Kirkland, Sarlo, \& Holton, 2018). Potassium has been documented to improve blood pressure control and to regulate the normal electrical activity of the heart (Filippini, Violi, D’Amico, \& Vinceti, 2017; Udensi \& Tchounwou, 2017).

Propolis is exposed to different sources of contamination brought by soil, plants, water, and air. In fact, during foraging, bees can transport toxic metals contained in the atmosphere, the honeydew, the nectar, or pollen of flowers into the hive (Perugini et al., 2011). Regarding heavy metals, lead and cadmium were not detected in all analyzed samples except S4 from the area of Settat which presented a low concentration of $\mathrm{Cd}(0.03 \mathrm{mg} / \mathrm{kg})$, which is under the maximum limit fixed by the EU Legislation at $(0.05 \mathrm{mg} / \mathrm{kg}$ ) (Commission Regulation, 2006). Taking into consideration that this sample was harvested from hives located in an agricultural area, indeed, the presence of Cd could be associated with the use of fertilizers and pesticides (Zoffoli et al., 2013).

For the minor elements, copper was not detected in propolis from
Sefrou (S2) and Settat (S6) areas, with the lowest detected concentration found in the sample of Agadir (S7) $(2.54 \mathrm{mg} / \mathrm{kg}$ ) and the highest concentration was referred to Boulemane station (S1) $(11.54 \mathrm{mg} / \mathrm{kg})$. The quantified concentration of zinc varied from 1.89 to $25.37 \mathrm{mg} / \mathrm{kg}$ in Errachidia (S5) and SidiKacem (S4) samples, respectively. However, zinc was not detected in the sample harvested from Agadir (S7). For nickel, the sample from Taounate (S3) had the lowest quantity $(0.13$ $\mathrm{mg} / \mathrm{kg}$ ) and the sample from Boulemane (S1) had the highest concentration $(2.10 \mathrm{mg} / \mathrm{kg})$. The amount of $\mathrm{Zn}$ found in our studied samples is lower than that showed in 25 Brazilian propolis samples (Souza, Zaluski, Veiga, \& Orsi, 2016). Micro-elements are known beneficial for our organism; in fact, they act in synergy with enzymes in the catalysis of several chemical reactions. The study of (Souza et al., 2016) shed light on the impact of the collection method and the harvest season on the minor and major mineral composition of propolis, in addition to the soil nature and plant buds.

\subsection{Structural characterization by ATR-FTIR spectroscopy}

FTIR peaks are attributed to stretching and bending vibrations of major structural groups present in the examined sample. IR spectra displayed in Fig. 2 showed a large difference between the sample peaks and their intensity, which goes on hand with the outcomes of physicochemical parameters, phytochemical profile and biological activities. The largest band observed was between 3550 and $3200 \mathrm{~cm}^{-1}$ and is attributed to intermolecular hydrogen bonds, $\mathrm{C}-\mathrm{H}$ stretch of a terminal alkyne and $\mathrm{O}-\mathrm{H}$ stretch of phenolic and aliphatic molecules $\left(3325 \mathrm{~cm}^{-1}\right)$ which is confirmed by the phenolic component profile (Table 5). A large peak between 2950 and $2900 \mathrm{~cm}^{-1}$ (Fig. 2B) is related to the presence of C-H stretch vibration in methyl groups. This peak (2950 and 2900 $\mathrm{cm}^{-1}$ ) was detected in all examined samples, but with different intensities; indeed, propolis S7 and S6 have the most intense peaks, while propolis $\mathrm{S} 1$ and $\mathrm{S} 2$ have less intense peaks. The peaks at approximately $2849 \mathrm{~cm}^{-1}$ (Fig. 2A) are associated also to C-H elongation symmetrical vibration of hydrocarbons (Wu, Sun, Zhao, Li, \& Zhou, 2008). The band between 1750 and 1725 is related to aliphatic esters (Fig. 2C) (Socrates, 2001, p. 332) and assigned also to the $(C=O)$ stretching vibration of lipids and flavonoids (Ibrahim, Zakaria, Zhari Ismail, \& Mohd, 2018). The peaks detected at $1735 \mathrm{~cm}^{-1}$ confirm the presence of a carbonyl group $(C=O)$ ester bond. This vibration could be related to monoesters of the bee wax fraction present in the raw propolis (Svečnjak et al., 2019). The peaks at $1700-1600 \mathrm{~cm}^{-1}$, more precisely between 1660 and $1610 \mathrm{~cm}^{-1}$ are assigned to the $\mathrm{N}-\mathrm{H}$ asymmetric stretching of amino acids in addition to $\mathrm{C}=\mathrm{C}$ and $\mathrm{C}=\mathrm{O}$ stretching vibration of flavonoids (Ibrahim et al., 2018). Absorption at $1463 \mathrm{~cm}^{-1}$ corresponding to the C-H bending vibration and aromatic stretching (Svečnjak, Marijanović, Okińczyc, Marek Kuś, \& Jerković, 2020) appears with different intensities which can explain compositional difference between the examined samples. The peaks between 1200 and $1100 \mathrm{~cm}^{-1}$ (Fig. 2C) corresponding to the $\mathrm{C}-\mathrm{O}$ asymmetric stretching ester vibration of

Table 3

Mineral elements content of propolis samples.

\begin{tabular}{|c|c|c|c|c|c|c|c|c|c|}
\hline Samples & $\mathrm{Ca}$ & $\mathrm{Na}$ & $\mathrm{K}$ & $\mathrm{Mg}$ & $\mathrm{Cu}$ & $\mathrm{Zn}$ & $\mathrm{Ni}$ & $\mathrm{Pb}$ & $\mathrm{Cd}$ \\
\hline S1 & $1748.36 \pm 22.45^{\mathrm{a}}$ & $516.43 \pm 3.47^{\mathrm{c}}$ & $711.34 \pm 9.85^{\mathrm{a}}$ & $502.61 \pm 11.45^{\mathrm{a}}$ & $11.54 \pm 1.24^{\mathrm{a}}$ & $11.25 \pm 0.58^{\mathrm{b}}$ & $0.78 \pm 0.04^{c}$ & nd & nd \\
\hline S2 & $857.69 \pm 9.11^{b c}$ & $19.40 \pm 9.41^{\mathrm{e}}$ & $327.12 \pm 14.67^{c}$ & $256.67 \pm 15.02^{\mathrm{cd}}$ & nd & $3.45 \pm 0.24^{\mathrm{bc}}$ & $2.10 \pm 0.08^{\mathrm{a}}$ & nd & nd \\
\hline S3 & $104.25 \pm 13.74^{\mathrm{f}}$ & $811.45 \pm 14.2^{\mathrm{b}}$ & $404.67 \pm 8.76^{b}$ & $148.57 \pm 14.64^{\mathrm{cd}}$ & $06.87 \pm 0.67^{\mathrm{a}}$ & $12.54 \pm 0.97^{\mathrm{b}}$ & $0.13 \pm 0.01^{\mathrm{d}}$ & nd & nd \\
\hline S4 & $698.25 \pm 15.62^{d}$ & $432.52 \pm 18.07^{d}$ & $142.68 \pm 7.85^{\mathrm{d}}$ & $467.43 \pm 5.97^{\mathrm{a}}$ & $05.87 \pm 1.14^{\mathrm{a}}$ & $25.37 \pm 2.34^{\mathrm{a}}$ & $0.91 \pm 0.01^{\mathrm{c}}$ & nd & nd \\
\hline S5 & $936.74 \pm 7.14^{\mathrm{bc}}$ & $967.04 \pm 25.78^{\mathrm{a}}$ & $123.74 \pm 24.46^{\mathrm{d}}$ & $389.75 \pm 17.64^{\mathrm{b}}$ & $05.68 \pm 3.64^{\mathrm{a}}$ & $1.89 \pm 0.02^{\mathrm{bc}}$ & $1.17 \pm 0.05^{\mathrm{b}}$ & nd & nd \\
\hline S6 & $1015.09 \pm 19.38^{b}$ & $947.60 \pm 5.59^{\mathrm{a}}$ & $408.87 \pm 10.90^{\mathrm{b}}$ & $311.92 \pm 13.60^{c}$ & nd & $7.85 \pm 0.41^{b}$ & $0.54 \pm 0.03^{d}$ & nd & $0.03 \pm 0.00$ \\
\hline S7 & $548.69 \pm 9.25^{\mathrm{e}}$ & $98.73 \pm 11.04^{\mathrm{e}}$ & $298.69 \pm 5.78^{c}$ & $309.84 \pm 22.94^{c}$ & $2.54 \pm 0.01^{\mathrm{a}}$ & nd & $0.94 \pm 0.01^{\mathrm{c}}$ & nd & nd \\
\hline Means \pm SD & $844.15 \pm 337.50$ & $499.01 \pm 270.9$ & $345.30 \pm 139.70$ & $340.97 \pm 96.25$ & $6.5 \pm 2.12$ & $10.39 \pm 5.99$ & $0.93 \pm 0.39$ & - & - \\
\hline Min & 104.25 & 19.40 & 123.74 & 256.67 & 2.54 & 1.89 & 0.13 & - & - \\
\hline Max & 1748.36 & 967.04 & 711.34 & 502.61 & 11.54 & 25.37 & 2.10 & - & 0.03 \\
\hline
\end{tabular}

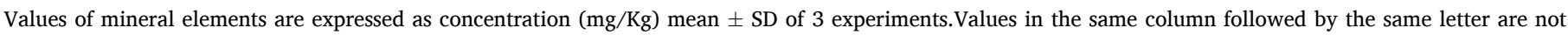
significantly different by Tukey's multiple range test $(p<0.05)$. nd: not detected. 
A

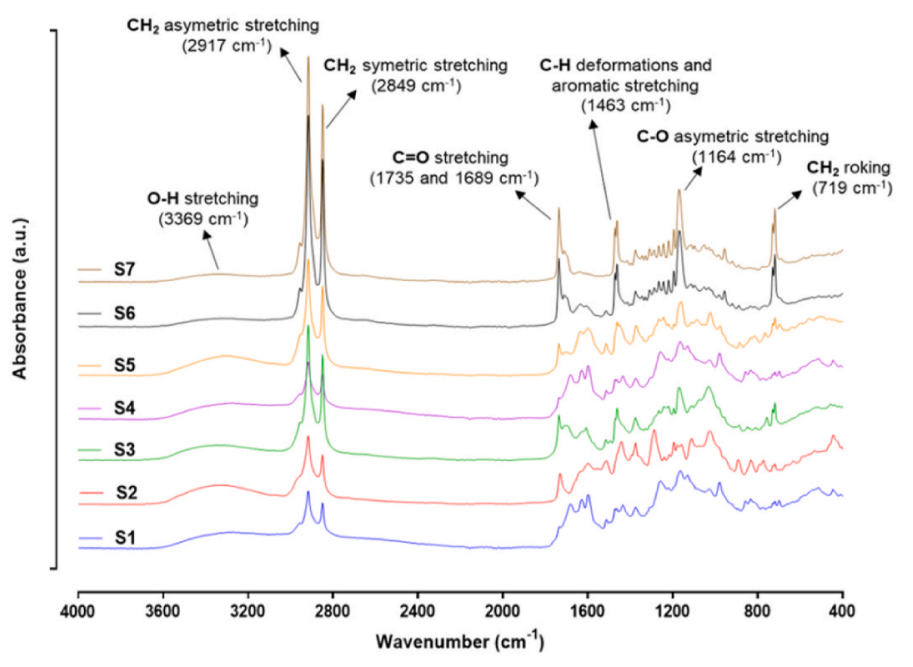

B

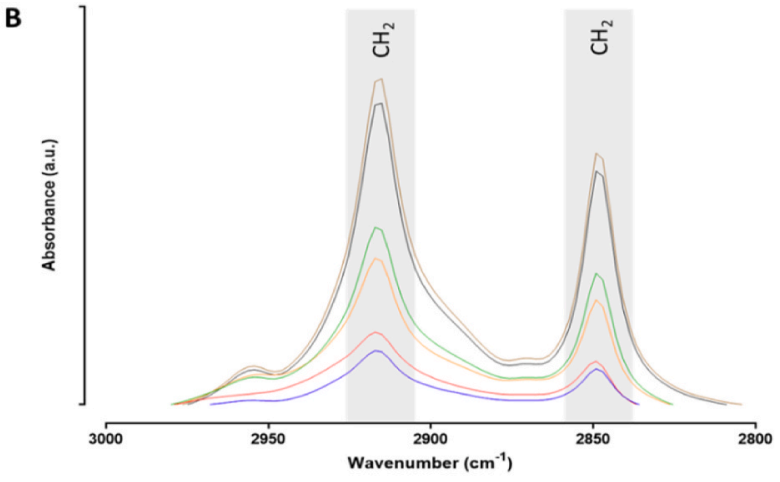

C

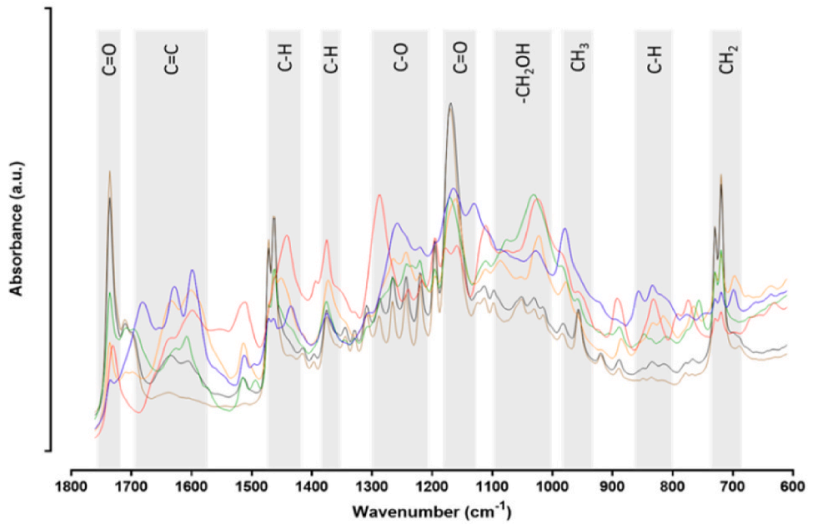

Fig. 2. FTIR-ATR spectrum of raw propolis samples. Spectral region from 4000 to $400 \mathrm{~cm}^{-1}$ (A), 3000-2800 $\mathrm{cm}^{-1}$ (B) and $1800-600 \mathrm{~cm}^{-1}$ (C).-S1; - S2; - S3; -S4; - S5; - S6;-S7.

Table 4

Phytochemical constituents, antioxidant activities, $\alpha$-Amylase and $\alpha$-Glucosidase inhibitory activities of propolis extracts.

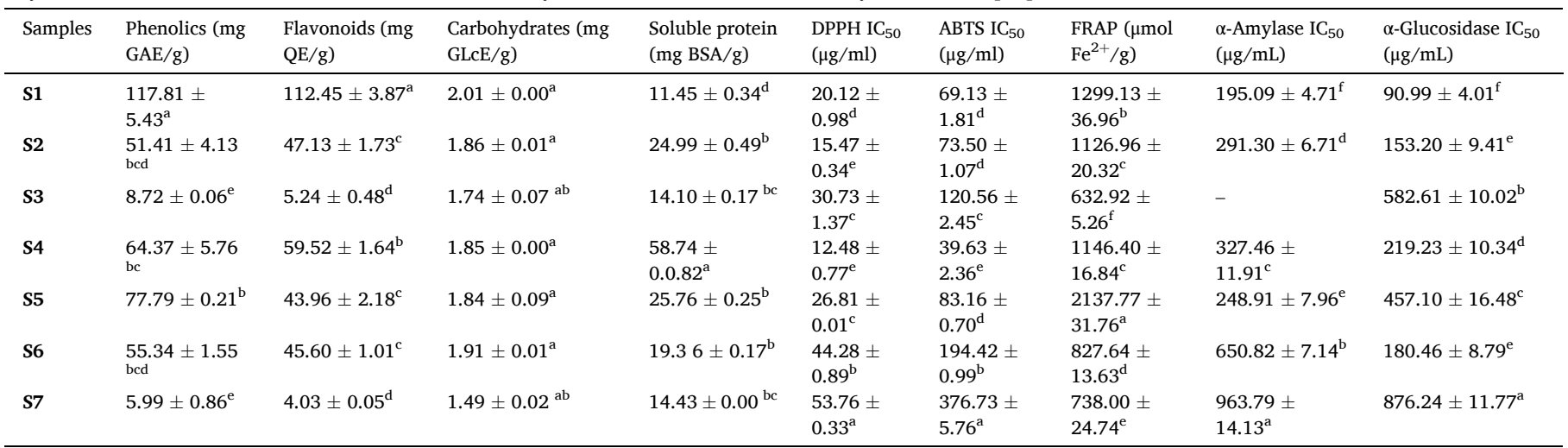

Values in the same column followed by the same letter are not significantly different by Tukey's multiple range test $(p<0.05)$.

aliphatic acids with a maximum absorption detected at $1164 \mathrm{~cm}^{-1}$ (Fig. 2A). The peaks detected at719 $\mathrm{cm}^{-1}$ are assigned to $\mathrm{CH}_{2}$ rocking of hydrocarbons (Svečnjak et al., 2019). Furthermore, a deformation effect of the $\mathrm{OH}$ functional group of phenols can be also detected in this region (Svečnjak et al., 2020). The spectral analysis (positions and intensities) of different propolis samples reflects the similarity between certain propolis varieties- (S1andS4), (S2, S3 and S5) and (S6 and S7) and a great difference between other samples, which are related to their specific botanical sources, pedo-climatic conditions and thus, compositional differences.

\subsection{Phytochemical analysis of propolis extracts}

\subsubsection{Total phenolic content}

Phenolic compounds are considered the main effective phytochemical components and are responsible for several biological activities of propolis (Cauich-Kumul \& Segura Campos, 2019, pp. 227-243). Furthermore, the solvent used and the extraction method influence the quantity and the selectivity of extract components (Rafińska et al., 2019). Phenolic compounds and other phytochemical constituents that have hydroxyl groups are mostly soluble in hydroethanolic solution and other polar solvents (Ferreira-Santos, Zanuso, Genisheva, Rocha, \& Teixeira, 2020). As indicated in Table 4, our results show that the total phenolic content of the analyzed samples ranged from $5.99 \pm 0.86$ to $117.81 \pm 5.43 \mathrm{mg} \mathrm{GAE} / \mathrm{g}$ for Agadir (S7) and Boulemane (S1) samples, respectively. These results are higher than those reported by (Miguel, Doughmi, Aazza, Antunes, \& Lyoussi, 2014) for different Moroccan propolis samples and lower than those shown for propolis samples from China and United States (Xu et al., 2019). The amount of phenolic compounds in propolis depends on the botanical 
Table 5

Phenolic compounds identification and quantification from propolis extracts.

\begin{tabular}{|c|c|c|c|c|c|c|c|}
\hline \multirow[t]{2}{*}{ Compounds } & \multicolumn{7}{|l|}{ Samples } \\
\hline & $\mathrm{S} 1$ & $\mathrm{~S} 2$ & S3 & S4 & S5 & S6 & S7 \\
\hline Catechin & $9.6 \pm 1.17$ & nd & nd & nd & nd & nd & nd \\
\hline Vanilic Acid & $5.6 \pm 0.90$ & nd & nd & nd & nd & nd & nd \\
\hline$p$-coumaric Acid + Epicatechin & $8.2 \pm 0.97^{\mathrm{b}}$ & $13.5 \pm 0.58^{\mathrm{b}}$ & $14.2 \pm 0.04^{\mathrm{b}}$ & $95.8 \pm 2.26^{\mathrm{b}}$ & $190.5 \pm 42.00^{\mathrm{a}}$ & $7.6 \pm 0.39^{\mathrm{b}}$ & $5.4 \pm 0.21^{\mathrm{bc}}$ \\
\hline$o$-Coumaric Acid & $77.5 \pm 49.26^{\mathrm{b}}$ & $20.4 \pm 4.33^{\mathrm{b}}$ & $13.3 \pm 5.18^{\mathrm{bc}}$ & $180.2 \pm 0.54^{\mathrm{a}}$ & $12.0 \pm 0.62^{\mathrm{bc}}$ & $58.1 \pm 0.38^{\mathrm{b}}$ & $4.1 \pm 0.10^{\mathrm{bc}}$ \\
\hline Ferulic Acid & $16.8 \pm 2.70^{\mathrm{bc}}$ & $10.6 \pm 0.42^{\mathrm{bc}}$ & $8.4 \pm 0.02^{b c}$ & $18.8 \pm 0.74^{\mathrm{b}}$ & $31.0 \pm 4.05^{\mathrm{a}}$ & $8.3 \pm 0.02^{\mathrm{bc}}$ & $8.6 \pm 0.15^{\mathrm{bc}}$ \\
\hline Ellagic Acid & $134.8 \pm 19.35^{\mathrm{a}}$ & $29.2 \pm 0.95^{\mathrm{b}}$ & $6.5 \pm 0.19^{b}$ & $35.4 \pm 3.79^{b}$ & $51.3 \pm 5.60^{\mathrm{b}}$ & $9.8 \pm 0.7^{\mathrm{b}}$ & $8.1 \pm 0.53^{\mathrm{b}}$ \\
\hline Naringin & $68.10 \pm 7.81^{\mathrm{a}}$ & $26.6 \pm 0.53^{\mathrm{ab}}$ & $21.5 \pm 1.06^{\mathrm{ab}}$ & $51.6 \pm 1.81^{\mathrm{a}}$ & $36.1 \pm 7.68^{a b}$ & $11.1 \pm 0.68^{\mathrm{abc}}$ & $7.6 \pm 0.89^{\mathrm{abc}}$ \\
\hline Hesperidin & $36.3 \pm 6.80^{\mathrm{b}}$ & $15.1 \pm 2.36^{\mathrm{c}}$ & $7.2 \pm 1.28^{\mathrm{c}}$ & $57.1 \pm 0.15^{\mathrm{a}}$ & $67.2 \pm 6.26^{\mathrm{a}}$ & $8.10 \pm 0.57^{c}$ & nd \\
\hline Apigenin & $32.4 \pm 6.18^{c}$ & $75.8 \pm 7.65^{c}$ & $7.1 \pm 0.12^{\mathrm{c}}$ & $134.8 \pm 1.99^{b}$ & $262.8 \pm 40.03^{\mathrm{a}}$ & $35.2 \pm 2.61^{\mathrm{c}}$ & $9.0 \pm 0.01^{c}$ \\
\hline Cinnamic Acid & $34.2 \pm 3.54^{\mathrm{a}}$ & $1.3 \pm 0.16^{\mathrm{cd}}$ & $1.6 \pm 0.05^{\mathrm{cd}}$ & $11.2 \pm 0.41^{\mathrm{c}}$ & $20.7 \pm 1.98^{\mathrm{b}}$ & $3.10 \pm 0.10^{c}$ & $0.9 \pm 0.07^{\mathrm{cd}}$ \\
\hline Resveratrol & $38.7 \pm 9.24^{\mathrm{a}}$ & $15.2 \pm 0.39^{\mathrm{b}}$ & $11.6 \pm 0.58^{\mathrm{b}}$ & $10.0 \pm 0.14^{\mathrm{b}}$ & $32.1 \pm 1.93^{\mathrm{a}}$ & $9.9 \pm 0.04^{\mathrm{b}}$ & $11.5 \pm 0.27^{\mathrm{b}}$ \\
\hline Rosmarinic Acid & $65.6 \pm 14.72^{\mathrm{a}}$ & $25.1 \pm 1.18^{\mathrm{b}}$ & $23.5 \pm 3.88^{\mathrm{b}}$ & $15.1 \pm 0.09^{\mathrm{b}}$ & $45.8 \pm 1.60^{\mathrm{a}}$ & $13.0 \pm 0.12^{\mathrm{b}}$ & $14.7 \pm 0.24^{\mathrm{b}}$ \\
\hline Rutin & $8.4 \pm 0.82^{\mathrm{a}}$ & $14.0 \pm 4.53^{\mathrm{a}}$ & $10.5 \pm 0.36^{\mathrm{a}}$ & $160.6 \pm 03.85^{\mathrm{a}}$ & $36.5 \pm 3.30^{\mathrm{a}}$ & $15.3 \pm 0.97^{\mathrm{a}}$ & $3.7 \pm 0.88^{\mathrm{a}}$ \\
\hline Chlorogenic Acid & nd & $9.4 \pm 0.69^{\mathrm{ab}}$ & $8.8 \pm 0.01^{\mathrm{ab}}$ & $11.2 \pm 0.16^{\mathrm{a}}$ & $32.0 \pm 7.23^{\mathrm{a}}$ & nd & nd \\
\hline Quercetin & $11.7 \pm 0.13^{c}$ & $19.2 \pm 0.52^{\mathrm{b}}$ & $7.1 \pm 0.19^{d}$ & $12.6 \pm 0.09^{c}$ & $26.7 \pm 0.05^{\mathrm{a}}$ & $6.6 \pm 0.91^{\mathrm{d}}$ & $5.1 \pm 0.94^{\mathrm{d}}$ \\
\hline Kaempferol & $11.7 \pm 0.13^{\mathrm{b}}$ & $19.2 \pm 0.53^{\mathrm{b}}$ & $7.1 \pm 0.19^{b}$ & $12.6 \pm 0.09^{\mathrm{b}}$ & $303.2 \pm 21.15^{\mathrm{a}}$ & $6.06 \pm 0.91^{\mathrm{b}}$ & $5.1 \pm 0.94^{\mathrm{b}}$ \\
\hline
\end{tabular}

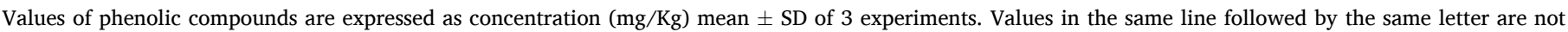
significantly different by Tukey's multiple range test $(p<0.05)$. nd: not detected.

source of resin and pedo-climatic conditions of the collecting region (Andrade, Denadai, de Oliveira, Nunes, \& Narain, 2017).

\subsubsection{Total flavonoid content}

Flavonoids are aromatic substances and powerful antioxidant components. Our study showed that the extract from Boulemane (S1) presents the highest value of flavonoids (112.45 $\pm 3.87 \mathrm{mg} \mathrm{QE} / \mathrm{g})$, while the lowest concentration corresponds to the extract of Agadir (S7) (4.03 \pm $0.05 \mathrm{mg} \mathrm{QE} / \mathrm{g}$ ) (Table 4). These results were within the range obtained in Moroccan and Polish propolis samples (El Menyiy, Bakour, El Ghouizi, El Guendouz, \& Lyoussi, 2021; Socha, Gałkowska, Bugaj, \& Juszczak, 2015). The high amount of flavonoids and phenolics occur in samples with high content in resin and low content in wax. Similar data were reported by (El Menyiy et al., 2021) in which a significant correlation was found between resin content, flavones/flavonols, and total phenolic compounds of twenty Moroccan propolis samples. A new report about the relationship between climatic conditions, metabolite-profile, and antioxidant activity has proved that the amount of flavonoids is strongly influenced by climatic conditions of each harvested station, which explain these major fluctuations between our examined samples and other propolis samples from different countries (do Nascimento et al., 2019).

\subsubsection{Carbohydrate and soluble protein contents}

Concerning nutritional parameters, our samples revealed for the first time the presence of carbohydrates and soluble proteins in Moroccan propolis (Table 4). Soluble proteins varied between $11.45 \mathrm{mg} \mathrm{BSAE} / \mathrm{g}$ in (S1) and $58.74 \mathrm{mg} \mathrm{BSAE} / \mathrm{g}$ in (S4). Regarding carbohydrates content, the sample from Agadir (S7) had the lowest concentration $(1.49 \mathrm{mg}$ GLcE/g), whereas extract harvested from Boulemane (S1) presented the highest concentration ( $2.01 \mathrm{mg} \mathrm{GLcE} / \mathrm{g}$ ). Plant buds are considered as potential sources of carbohydrates in propolis (Ahangari, Naseri, \& Vatandoost, 2018). Additionally, harvesting techniques may influence the carbohydrate composition of propolis due to sugar residues from honey (Fikri, Popova, Sulaeman, \& Bankova, 2020).

\subsubsection{Antioxidant activity of propolis extracts}

In the present work, the antioxidant activity was evaluated by the ABTS, DPPH and FRAP tests.

Antioxidant activity should not be concluded based on a single antioxidant test model (Alam, Bristi, \& Rafiquzzaman, 2013; Ferreira-Santos, Genisheva, Botelho, Rocha, \& Teixeira, 2021; Singh \& Singh, 2008). And in practice several in vitro test procedures should be performed to assess antioxidant activities with the samples of interest.
Another aspect is that antioxidant test models vary in different respects; therefore, it is difficult to compare fully one method to other one. Moreover, it is important to perform a second screening using ex vivo models (e.g. cell assays for ROS determination), and in vivo studies (e.g. lipid peroxidation and the levels of endogenous antioxidant enzymes) (Ferreira-Santos et al., 2021).

The Free radical scavenging assay DPPH assay is based on the measurement of the scavenging capacity of antioxidants. DPPH assay consists in the reduction of the 2,2-diphenyl-1-picryl-hydrazyl-hydrate (DPPH•) radical in the presence of hydrogen-donating antioxidant, and in the formation of the non-radical DPPH-H form at the end of the reaction (Ferreira-Santos, Genisheva, et al., 2020). The DPPH method is a valid, easy, accurate, sensitive, and economic method to evaluate scavenging activity of antioxidants of fruits and vegetables or extracts, since the radical is stable and need not to be generated as in other scavenging assays. The results are highly reproducible and comparable to other scavenging methods such as ABTS (Singh \& Singh, 2008).

The ABTS radical cation decolorization assay is a spectrophotometric method widely used for the assessment of antioxidant activity of various substances(Erel, 2004). Scavenging activity of ABTS radical cation $\left(\mathrm{ABTS}^{\bullet+}\right.$ ) (ABTS assay) is based on the interaction between antioxidant components and ABTS radical, that, in the presence of antioxidant compounds, the $\mathrm{ABTS}^{\bullet+}$ nitrogen atom quenches the hydrogen atom, producing the solution decolorization (Ferreira-Santos, Genisheva, et al., 2020).

Ferric reducing antioxidant power (FRAP assay) consists in the ability of extracts to reduce ferric ions $\left(\mathrm{Fe}^{3+}\right.$ to $\left.\mathrm{Fe}^{2+}\right)$, in the form of ferric TPTZ at a low $\mathrm{pH}$. This reduction will result in a color change (Ferreira-Santos et al., 2021).

As shown in Table 4, the ABTS assay showed a significant variation between samples, the sample of SidiKacem area (S4) expressed the highest inhibition percentage of ABTS free radical $\left(\mathrm{IC}_{50}=39.63 \mu \mathrm{g} / \mathrm{mL}\right.$ ). Propolis samples of Agadir (S7) that had the lowest phenolic content $(5.99 \pm 0.86 \mathrm{mg} \mathrm{GAE} / \mathrm{g})$ and flavonoids content $(4.03 \pm 0.05 \mathrm{mg} \mathrm{QE} / \mathrm{g})$ exhibited the lowest ABTS radical scavenging capacity, $\mathrm{IC}_{50}=376.73$ $\mu \mathrm{g} / \mathrm{mL}$. These values were lower than those reported recently for twenty Moroccan propolis samples from different origins, in which the concentration of propolis required to inhibit $50 \%$ of ABTS was between 0.026 and $1.529 \mathrm{mg} / \mathrm{mL}$ (El Menyiy et al., 2021). The obtained results were higher than that observed for Trolox $\left(\mathrm{IC}_{50}=23.15 \pm 4.0 \mu \mathrm{g} / \mathrm{mL}\right.$ ). Substantially different ABTS scavenging capacities were exhibited by various phenolic compounds isolated from propolis, viz caffeic acid $\left(\mathrm{IC}_{50}=4.73 \pm 0.02 \mu \mathrm{g} / \mathrm{mL}\right)$, galangin $\left(\mathrm{IC}_{50}=8.73 \pm 0.02 \mu \mathrm{g} / \mathrm{mL}\right)$, ferulic acid $\left(\mathrm{IC}_{50}=21.62 \pm 0.10 \mu \mathrm{g} / \mathrm{mL}\right), p$-coumaric acid $\left(\mathrm{IC}_{50}=23.46\right.$ 
$\pm 0.01 \mu \mathrm{g} / \mathrm{mL}$ ) (Yang et al., 2011). These compounds were quantified in all analyzed samples at different concentrations, which prove their contribution to the antioxidant activity of propolis and explains the wide ABTS scavenging activities between the samples.

Regarding free radical scavenging capacity (DPPH), the concentration of propolis required to inhibit 50\% of DPPH is shown in Table 4. The highest capacities were obtained in sample from SidiKacem (S4) $\left(\mathrm{IC}_{50}=\right.$ $12.48 \mu \mathrm{g} / \mathrm{mL}$ ) and Sefrou (S2) $\left(\mathrm{IC}_{50}=15.47 \mu \mathrm{g} / \mathrm{mL}\right.$ ) with the lowest activities being found in propolis samples from Agadir (S7) $\left(\mathrm{IC}_{50}=\right.$ $53.76 \mu \mathrm{g} / \mathrm{mL}$ ) and Settat (S6) $\left(\mathrm{IC}_{50}=44.28 \mu \mathrm{g} / \mathrm{mL}\right)$. These values are within the range of values reported for fourteen propolis samples collected from different regions of Morocco, with $\mathrm{IC}_{50}$ values between $0.025 \mathrm{mg} / \mathrm{mL}$ and $1.813 \mathrm{mg} / \mathrm{ml}$ (El-Guendouz et al., 2016) and higher than observed for trolox $\left(\mathrm{IC}_{50}=10.81 \pm 0.1 \mu \mathrm{g} / \mathrm{mL}\right.$ ).

For the FRAP test, the reducing antioxidant activity was largely different between analyzed samples. Propolis from Errachidia (S5) show the highest value $\left(2137.77 \mu \mathrm{mol} \mathrm{Fe} 2^{+} / \mathrm{g}\right)$ and the lowest value was exhibited by sample from Taounate (S3) $\left(632.92 \mu \mathrm{mol} \mathrm{Fe} 2^{+} / g\right)$. These results are higher than those obtained by (Falcão et al., 2013) for Croatian propolis, in which FRAP values ranging between 0.04 and 1.3 mmol Fe $2^{+} / \mathrm{g}$. Substantially different capacities in FRAP assay oscillating between 0.1 and $0.8 \mathrm{mmol} \mathrm{Fe} 2^{+} / \mathrm{g}$ were detected in propolis samples from Adriatic Sea islands (Svečnjak et al., 2020). The propolis extracts indicate potent and large differences of antioxidant activities, which are possibly related to their phytochemical constituents, mainly, phenolic components. These results allow us to affirm the beneficial use of propolis matrices for food, nutraceutical, or pharmaceutical applications.

3.4.5. $\alpha$-Amylase and $\alpha$-glucosidase inhibitory activities of propolis extracts $\alpha$-glucosidase and $\alpha$-amylase are humans carbohydrate digesting enzymes (Subramanian, Asmawi, \& Sadikun, 2008). Their inhibition plays an important role in the prevention of type 2 diabetes (T2D) by the stabilization of postprandial blood glucose (Murai et al., 2002). Moroccan propolis has been the subject of numerous studies including the prevention and treatment of diabetes, but only very few studies have focused on their activity on $\alpha$-glucosidase and $\alpha$-amylase inhibitory as a therapeutic way of T2D management. In this context, hydro-alcoholic extracts of different Moroccan propolis samples were evaluated (see Table 4). The results revealed that all propolis extracts had $\alpha$-amylase inhibitory activity except the propolis collected from SidiKacem (S4). The $\mathrm{IC}_{50}$ of examined samples ranged between $195.78 \pm 5.1$ and 963.64 $\pm 6.7 \mu \mathrm{g} / \mathrm{mL}$, with the highest activity on the sample from Boulemane region (S1) and the lowest activity from Agadir (S7). These results were higher than Acarbose $\left(\mathrm{IC}_{50}=35.42 \pm 1.0 \mu \mathrm{g} / \mathrm{mL}\right.$ ) (Ferreira-Santos, Genisheva, et al., 2020). Regarding $\alpha$-glucosidase inhibitory activity, the $\mathrm{IC}_{50}$ values showed that the sample from Boulemane (S1) has the lowest $\mathrm{IC}_{50}$ value $(91.7 \pm 3.6 \mu \mathrm{g} / \mathrm{mL})$, while, the propolis extract from Agadir (S7) displayed the highest $\mathrm{IC}_{50}$ value, $870.6 \pm 13.4 \mu \mathrm{g} / \mathrm{mL}$ (Table 4 ). These differences may be related to their distinct individual phenolic components. Our results were lower than that reported by(Ferreira-Santos, Genisheva, et al., 2020). for acarbose $\left(\mathrm{IC}_{50}=11,000 \pm 1.0\right.$ $\mu \mathrm{g} / \mathrm{mL}$ ) and go in hand with those of (El-Guendouz et al., 2016), who studied 21 Moroccan propolis samples and they showed that $\alpha$-amylase inhibitory ranged from $18 \pm 97.1 \mu \mathrm{g} / \mathrm{mL}$ to $3632 \pm 97 \mu \mathrm{g} / \mathrm{mL}$ and $\alpha$-glucosidase inhibitory activity ranged from $6 \pm 1.6 \mu \mathrm{g} / \mathrm{mL}$ to $746 \pm$ $16 \mu \mathrm{g} / \mathrm{mL}$.
Overall, it is shown that propolis from Agadir (S7), with the lowest $\alpha$-glucosidase and $\alpha$-amylase inhibitory activity, has the highest amount of wax and the lowest concentration of phenolic components. On the other hand, the best $\alpha$-glucosidase and $\alpha$-amylase inhibitory activities were exhibited by the sample harvested from Boulemane(S1) that had the highest amount of resin, flavonoid, and phenolic contents. A significant correlation was found between total phenolic content, total flavonoid content, and $\alpha$-amylase activity (Table 6). This correlation has also been documented by (El-Guendouz et al., 2016) for twenty-one Moroccan propolis samples, which means that phenolic compounds influence largely the $\alpha$-amylase activity.

These results indicate that propolis extracts have a powerful inhibitory action on these two digestive enzymes. Hence, it can be recommended as an ideal alternative candidate for preventing and managingT2D.

\subsubsection{Individual phenolic compounds}

A total of 16 phenolic compounds were tentatively identified by UHPLC-DAD in the studied propolis samples. The quantification of phenolic components in the propolis extracts was carried out to understand the phytochemical difference between all analyzed samples collected from different geographical locations of Morocco and their influence on studied biological activities. As indicated in Table 5, ellagic acid $(134.8 \pm 19.35 \mathrm{mg} / \mathrm{kg}$ ) was the most abundant component quantified in S1, apigenin $(75.8 \pm 7.65 \mathrm{mg} / \mathrm{kg})$ in S2, $o$-coumaric acid in S4 $(180.2 \pm 0.54 \mathrm{mg} / \mathrm{kg})$ and in $\mathrm{S} 6(58.1 \pm 0.38 \mathrm{mg} / \mathrm{kg})$, kaempferol in S5 $(303.02 \pm 21.15 \mathrm{mg} / \mathrm{kg})$, and rosmarinic acid in S3 $(23.5 \pm 3.88 \mathrm{mg} / \mathrm{kg})$ and $\mathrm{S} 7(14.7 \pm 0.24 \mathrm{mg} / \mathrm{kg})$. The studied samples showed a wide difference of phytochemical profile which is mainly related to specific botanical sources of each harvested station (Table 1). The phytochemical composition of propolis depends strongly on its botanic origin, harvesting period, and climatic factors (Bueno-Silva, Marsola, Ikegaki, Alencar, \& Rosalen, 2017). In fact, qualitative and quantitative differences of propolis compounds reflect the interaction between the plants' resin material and the growing environments (El Menyiy et al., 2021). In turn, this rich and varied composition influences the antioxidant potential of propolis and gives it an extensive range of biological and pharmacological properties (Pasupuleti, Sammugam, Ramesh, \& Gan, 2017). For instance, apigenin plays particular importance in the management of diabetes by stimulating insulin secretion and promoting hepatic glycogen storage(El Barky, El-Said, Sadek, \& Mohamed, 2019).

Kaempferol, a natural flavonol presents in beehive products has been shown to inhibit cell proliferation and induces apoptosis in colorectal cancer cells through the down-regulation of PI3K-Akt signaling pathway and/or the suppression of thymidylate synthase (Li et al., 2019). In the same context, several studies have reported that ellagic acid, an hydroxybenzoic acid presents in many functional foods possess a wide spectrum of pharmacological properties including, anti-cancer effect (Cheshomi, Bahrami, \& Matin, 2020), neuroprotective potential (Gupta et al., 2021), anti-microbial and anti-viral activities(Shakeri, Zirak, \& Sahebkar, 2018).

Catechin and vanillic acid were not detected in all examined samples, except in propolis from Boulemane (S1), which explains the influence of plant source on the phenolic composition. These results are in agreement with (Gargouri, Osés, Fernández-Muiño, Sancho, \& Kechaou, 2019) where catechin was not detected in propolis samples from four different regions of Tunisia. Chlorogenic acid was not detected in

Table 6

Pearson correlation coefficients between phenolics, flavonoids and antioxidant activity (ABTS, FRAP, DPPH), $\alpha$-amylase, $\alpha$-glucosidase inhibitory activities.

\begin{tabular}{|c|c|c|c|c|c|c|c|}
\hline & Phenolics & Flavonoids & ABTS & FRAP & DPPH & $\alpha$-amylase & $\alpha$-glucosidase \\
\hline Phenolics & 1 & $0.958 * * *$ & -0.627 & 0.641 & -0.562 & $-0.842^{*}$ & -0.405 \\
\hline Flavonoids & & 1 & -0.592 & 0.416 & -0.581 & -0.759 & -0.555 \\
\hline
\end{tabular}

" Correlation is significant at the level $p<0: 05 . * *$ Correlation is significant at the level $p<0: 01$. ***Correlation is significant at the level $p<0: 001$. 
samples S1, S6, and S7; and hesperidin was not detected in the S7. The amount of resveratrol found in all analyzed samples was higher than that signaled by (Ristivojević et al., 2020) for Serbian, Turkish, Russian and Chinese propolis samples. Twenty-six phenolic compounds were previously detected in four Moroccan propolis samples, where pinobanksin, caffeic acid isoprenyl ester, isosakuranetin, caffeic acid, galangin and chrysin were the predominant phenolic components identified (Falcão et al., 2019). Thus, Moroccan propolis could have its place in the pharmaceutical revolution and the search for new natural drugs with high therapeutic efficacy. According to the results shown in Table 4, the sample from Boulemane (S1) that had the highest content of total phenolic and flavonoids exhibited the highest ABTS scavenging activity and best $\alpha$-amylase and $\alpha$-glucosidase inhibition. The lowest phenolic profile was found in the samples harvested from S3 and S7, accompanied

A

\section{Biplot (axes PC1 and PC2: 54.4\%)}

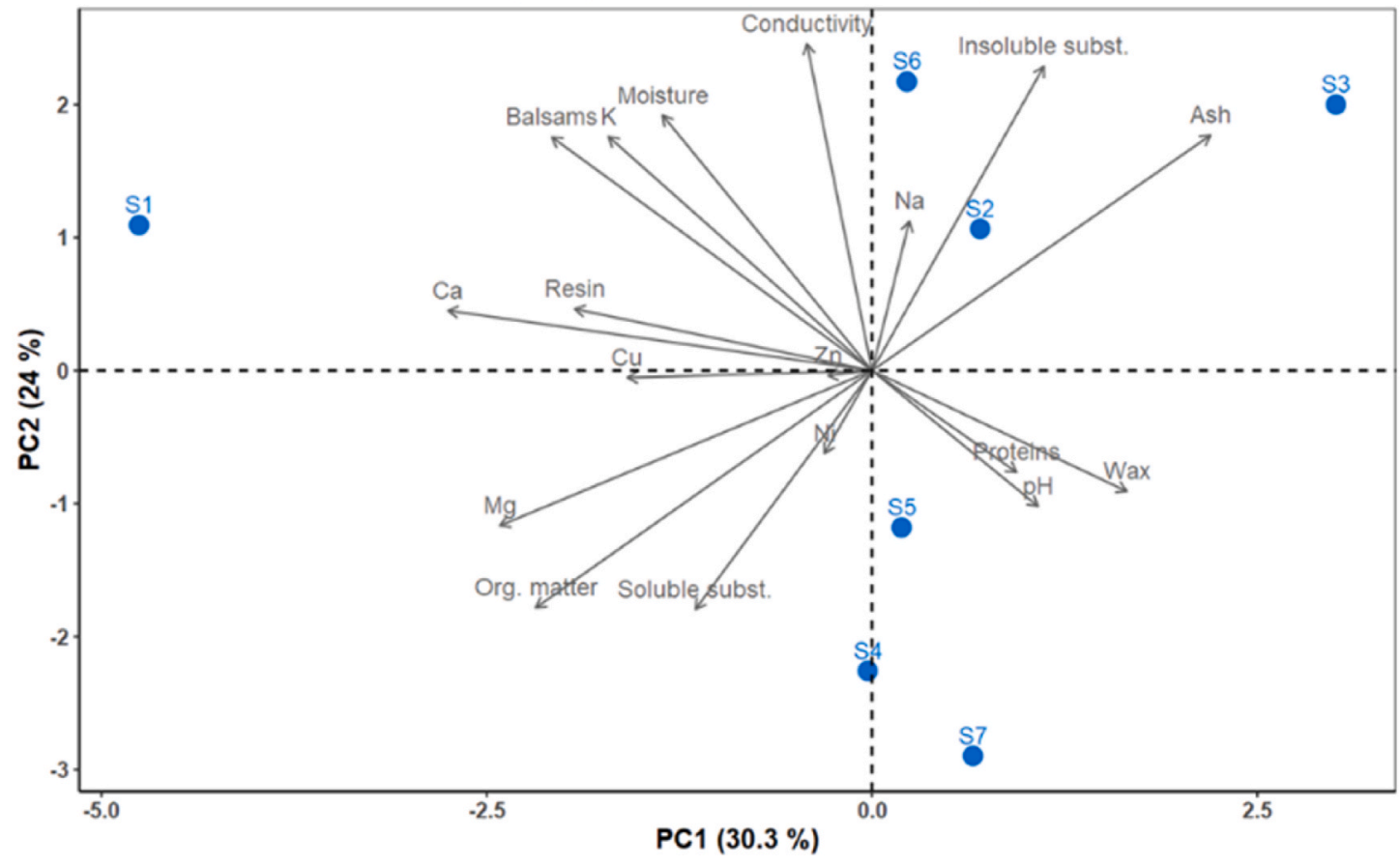

\section{B}

Biplot (axes PC1 and PC2: 77.9\%)

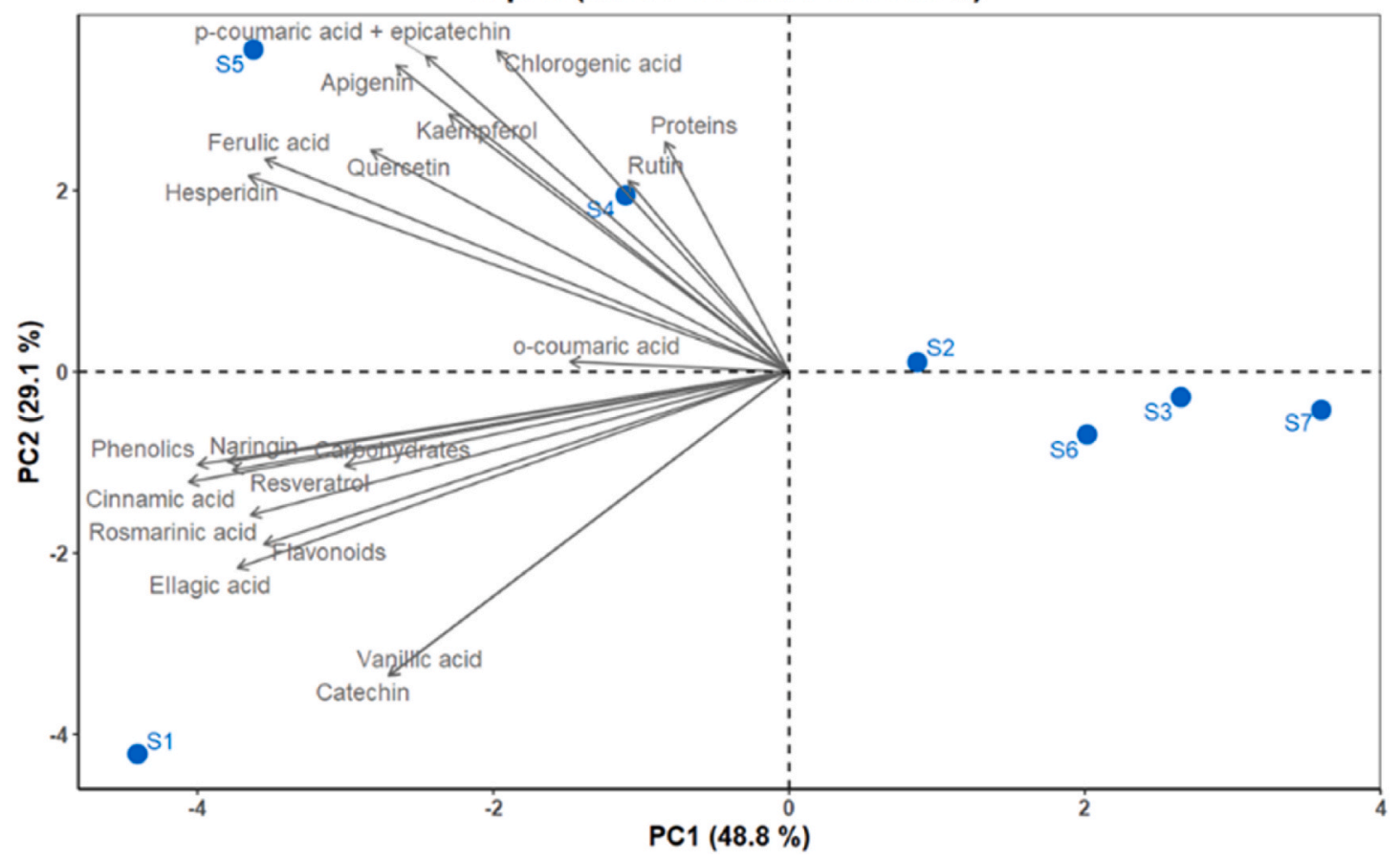

Fig. 3. Principal component analysis (PCA). (A) biplots for physicochemical analysis of studied propolis samples, (B) biplotsfor phytochemical results of hydroethanolic propolis extracts 
by lowest flavonoid contents and poorest antioxidant activity, displayed the lowliest $\alpha$-amylase and $\alpha$-glucosidase inhibitory activities. In the same context, in the data published by (Touzani et al., 2018) for seven Moroccan propolis samples, a strong correlation was observed between the chemical profile, total phenolic content, flavonoids, and antioxidant activity, which is not the case in the present study (Table 6).

\subsubsection{Correlations and multivariate analysis}

A Principle component analysis (PCA) was applied to the previously obtained results and the main outcomes are presented in Fig. 3.

Fig. 3A, represents the PCA for physicochemical analysis of the studied propolis samples raw materials, and thePC1 and PC2 explained variance of $54.4 \%$. The first component (PC1) explained $30.3 \%$ and represents in its positive part insoluble substance, ash, Na, proteins, wax and $\mathrm{pH}$. The negative part includes conductivity, moisture, balsams, $\mathrm{K}$, resin, $\mathrm{Ca}, \mathrm{Cu}, \mathrm{Mg}, \mathrm{Zn}, \mathrm{Ni}$, organic matter, and soluble substance. The second component (PC2) explained $24 \%$ and regrouped in its positive part the propolis sample from Boulemane (S1), the sample from Sefrou (S2), the sample from Taounate (S3), and the sample from Settat (S6). These samples shared characteristics regarding ash, insoluble substance, $\mathrm{Na}$, conductivity, moisture, balsams, $\mathrm{K}$, resin, $\mathrm{Ca}$, while the negative part includes $\mathrm{Mg}$, organic matter, soluble substance, $\mathrm{Ni}$, proteins, $\mathrm{pH}$, and wax.

Fig. 3B, represent the PCA for phytochemical results of hydroethanolic propolis extracts, the two principal components (PC1 and PC2) explained variance of $77.9 \%$.The first component explained $48.8 \%$ and represents in its negative part all investigated phytochemical analysis, whereas the second component explained $29.1 \%$, and represents in its positive part, $p$-coumaric acid + epicatechin, apigenin, chlorogenic acid, ferulic acid, hesperidin, quercetin, kaempferol, proteins, rutin, and $o$-coumaric acid. While, its negative part represents: phenolics, naringin, carbohydrates, resveratrol, cinnamic acid, rosmarininc acid, flavonoids, ellagic acid, vanillic acid, and catechin.

The sample from Sidi Kacem (S4) and the sample from Errachidia (S5) shared characteristics regarding proteins, rutin, chlorogenic acid, $p$ coumaric acid + epicatechin, apigenin, kaempferol, quercetin, ferulic acid, and hesperidin. Considering the similarities of the samples, the samples S1, S4, and S5 from Boulemane, Sidi Kacem, and Errachidia respectively, have high flavonoids and phenolic components, with the best-studied activities were recorded to the S1.

The relationship between total phenolic content, total flavonoid content, and the biological activities of propolis (ABTS scavenging activity, $\alpha$-amylase, and $\alpha$-glucosidase inhibitory activities) was performed using the Pearson correlation coefficient (Table 6). A significant ( $\mathrm{p}<$ 0.001 ) positive correlation was observed between phenolics and flavonoids, whilea negative correlation was obtained between phenolics, flavonoids and $\mathrm{IC}_{50}$ values of ABTS and DPPH. However, this correlation was not significant as expected. Similar results were obtained elsewhere (Teixeira, Negri, Salatino, \& Stringheta, 2010; H.; Zhang, YANG, \& ZHOU, 2018). Besides phenolic compounds, the most likely suggestion of this no significant correlation may be related tothe presence of other antioxidant compounds that could be involved in the observed antioxidant activity such as ascorbic acid and terpenoids (Mouhoubi-Tafinine, Ouchemoukh, \& Tamendjari, 2016; Zhang, Cai, Chen, Ji, \& Sun, 2020). On the other hand, a significant $(\mathrm{p}<0.01)$ negative correlation was observed between phenolics, flavonoids and $\alpha$-amylase inhibitory activity, while no significant correlation was obtained between phenolics, flavonoids, and $\alpha$-glucosidase inhibition. It was reported that hesperidin and quercetin, flavonoids compounds present in all examined propolis expect sample (S7) exhibit potent $\alpha$-amylase inhibition by establishing high hydrogen and hydrophobic bindings between the flavonoids and the enzyme (Martinez-Gonzalez, Díaz-Sánchez, De La Rosa, Bustos-Jaimes, \& Alvarez-Parrilla, 2019). In addition, a previous study has suggested that the natural antioxidant compounds may affect the disulfide bridges located on the surface of $\alpha$-amylase and induce structural alterations that may negatively affect the activity of the enzyme
(Ademiluyi \& Oboh, 2013).

\section{Conclusion}

Overall, the data presented in this report shows a wide range of phenolic compounds in propolis extracts, belonging to different chemical groups: phenolic acids, flavanones, flavanols, flavonoids, and stilbens. Moreover, all examined samples revealed a great variability in their mineral contents, physicochemical parameters, antioxidant activity (ABTS, DPPH and FRAP), $\alpha$-amylase, and $\alpha$-glucosidase inhibitory activities, which could be related to the plant origin and pedoclimatic characteristics of each harvested station. All propolis samples are in line with the international standards of propolis quality control. This data provides new and useful information in the standardization procedure of Moroccan propolis and supports the development of research on this natural product.

\section{Funding}

This work was supported by a grant from University Sidi Mohamed Ben Abdallah for.

Laboratory of Natural Substances, Pharmacology, Environment, Modeling, Health and Quality of Life (SNAMOPEQ).

This research was funded by the Portuguese Foundation for Science and Technology (FCT) under the scope of the strategic funding of UIDB/ 04469/2020 unit and BioTecNorteoperation (NORTE-01-0145-FEDER000004) funded by the European Regional Development Fund (FEDER) under the scope of Norte2020-Programa Operacional Regional do Norte. Zlatina Genisheva is supported by the project OH2O (POCI-01-0145FEDER-029145) funded by FCT and FEDER under the scope of ProgramaOperacional de Competividade e Internacionalizaçao (POCI)COMPETE 2020 and PORTUGAL 2020.

\section{Author contributions}

Hassan Laaroussi: Designed and performed experimental investigations, data analysis and writing-original draft preparation. Pedro Ferreira-Santos: Designed and performed the experiments, data analysis, and manuscript review. Zlatina Genisheva: Performed UHPLCDAD analysis, identification and quantification of bioactive compounds and manuscript review. Meryem Bakour: Designed the experiments, data treatment and manuscript review. Driss Ousaaid: Data analysis and manuscript review. José Antonio Teixeira: Methodology of work and manuscript review. Badiaa Lyoussi: Data analysis, manuscript review and submission procedure.

\section{Declaration of competing interest}

The authors declare that there are no conflicts of interest.

\section{Appendix A. Supplementary data}

Supplementary data to this article can be found online at https://doi. org/10.1016/j.fbio.2021.101160.

\section{References}

Ademiluyi, A. O., \& Oboh, G. (2013). Soybean phenolic-rich extracts inhibit key-enzymes linked to type 2 diabetes ( $\alpha$-amylase and $\alpha$-glucosidase) and hypertension

(angiotensin I converting enzyme) in vitro. Experimental \& Toxicologic Pathology, 65 (3), 305-309.

Ahangari, Z., Naseri, M., \& Vatandoost, F. (2018). Propolis: Chemical composition and its applications in endodontics. Iranian Endodontic Journal, 13(3), 285.

Alam, M. N., Bristi, N. J., \& Rafiquzzaman, M. (2013). Review on in vivo and in vitro methods evaluation of antioxidant activity. Saudi Pharmaceutical Journal, 21(2), 143-152. https://doi.org/10.1016/j.jsps.2012.05.002

Andrade, J. K. S., Denadai, M., de Oliveira, C. S., Nunes, M. L., \& Narain, N. (2017). Evaluation of bioactive compounds potential and antioxidant activity of brown, 
green and red propolis from Brazilian northeast region. Food Research International, 101, 129-138.

Anjum, S. I., Ullah, A., Khan, K. A., Attaullah, M., Khan, H., Ali, H., et al. (2019). Composition and functional properties of propolis (bee glue): A review. Saudi Journal of Biological Sciences, 26(7), 1695-1703.

Bankova, V., Bertelli, D., Borba, R., Conti, B. J., da Silva Cunha, I. B., Danert, C., et al. (2019). Standard methods for Apis mellifera propolis research. Journal of Apicultural Research, 58(2), 1-49.

Bogdanov, S., Martin, P., \& Lullmann, C. (2002). Harmonised methods of the international honey commission. Swiss Bee Research Centre, FAM, Liebefeld.

Bradford, M. M. (1976). A rapid and sensitive method for the quantitation of microgram quantities of protein utilizing the principle of protein-dye binding. Analytical Biochemistry, 72(1), 248-254. https://doi.org/10.1016/0003-2697(76)90527-3

Bueno-Silva, B., Marsola, A., Ikegaki, M., Alencar, S. M., \& Rosalen, P. L. (2017). The effect of seasons on Brazilian red propolis and its botanical source: Chemical composition and antibacterial activity. Natural Product Research, 31(11), 1318-1324.

Cauich-Kumul, R., \& Segura Campos, M. R. (2019). Chapter 12 - bee propolis: Properties, chemical composition, applications, and potential health effects. In M. R. S. Campos (Ed.), Bioactive compounds. Woodhead Publishing. https://doi.org/10.1016/B978-012-814774-0.00012-8.

Cheng, X., Zhang, J., \& Hu, F. (2017). Antihyperglycemic effect of propolis and its molecular mechanism: A review. Natural Product Research and Development, 6, 28.

Cheshomi, H., Bahrami, A. R., \& Matin, M. M. (2020). Ellagic acid and human cancers: A systems pharmacology and docking study to identify principal hub genes and main mechanisms of action. Molecular Diversity, 1-17.

Commission Regulation. (2006). Setting maximum levels for certain contaminants in foodstuffs. No 1881/2006).

Cseke, L. J., Kirakosyan, A., Kaufman, P. B., Warber, S., Duke, J. A., \& Brielmann, H. L. (2016). Natural products from plants. CRC press.

Dias, L. G., Pereira, A. P., \& Estevinho, L. M. (2012). Comparative study of different Portuguese samples of propolis: Pollinic, sensorial, physicochemical, microbiological characterization and antibacterial activity. Food and Chemical Toxicology, 50(12), 4246-4253.

El Barky, A. R., El-Said, K. S., Sadek, M. E.-R., \& Mohamed, T. M. (2019). Anti-diabetic activity of Egyptian celery apigenin. Asian Journal of Dairy and Food Research, 38(4).

El Menyiy, N., Bakour, M., El Ghouizi, A., El Guendouz, S., \& Lyoussi, B. (2021). Influence of geographic origin and plant source on physicochemical properties, mineral content, and antioxidant and antibacterial activities of Moroccan propolis. International Journal of Food Science, 2021.

El-Guendouz, S., Aazza, S., Lyoussi, B., Antunes, M. D., Faleiro, M. L., \& Miguel, M. G. (2016). Anti-acetylcholinesterase, antidiabetic, anti-inflammatory, antityrosinase and antixanthine oxidase activities of Moroccan propolis. International Journal of Food Science and Technology, 51(8), 1762-1773. https://doi.org/10.1111/ijfs.13133

El-Guendouz, S., Aazza, S., Lyoussi, B., Antunes, M. D., Faleiro, M. L., \& Miguel, M. G. (2016). Anti-acetylcholinesterase, antidiabetic, anti-inflammatory, antityrosinase and antixanthine oxidase activities of Moroccan propolis. International Journal of Food Science and Technology, 51(8), 1762-1773.

Erel, O. (2004). A novel automated direct measurement method for total antioxidant capacity using a new generation, more stable ABTS radical cation. Clinical Biochemistry, 37(4), 277-285.

Escriche, I., \& Juan-Borrás, M. (2018). Standardizing the analysis of phenolic profile in propolis. Food Research International, 106, 834-841.

Falcão, S. I. D. M. (2013). Bioactive properties. In Chemical composition of Portuguese propolis.

Falcão, S. I., Calhelha, R. C., Touzani, S., Lyoussi, B., Ferreira, I. C., \& Vilas-Boas, M. (2019). In vitro interactions of Moroccan propolis phytochemical's on human tumor cell lines and anti-inflammatory properties. Biomolecules, 9(8), 315.

Falcão, S. I., Freire, C., \& Vilas-Boas, M. (2013). A proposal for physicochemical standards and antioxidant activity of Portuguese propolis. Journal of the American Oil Chemists' Society, 90(11), 1729-1741.

Ferreira-Santos, P., Genisheva, Z., Botelho, C., Rocha, C., \& Teixeira, J. A. (2021). Valorization of natural antioxidants for nutritional and health applications. In Antioxidants. IntechOpen.

Ferreira-Santos, P., Genisheva, Z., Botelho, C., Santos, J., Ramos, C., Teixeira, J. A., et al. (2020). Unravelling the biological potential of Pinus pinaster bark extracts. Antioxidants, 9(4), 334.

Ferreira-Santos, P., Genisheva, Z., Pereira, R. N., Teixeira, J. A., \& Rocha, C. M. (2019). Moderate electric fields as a potential tool for sustainable recovery of phenolic compounds from Pinus pinaster bark. ACS Sustainable Chemistry \& Engineering, 7(9), 8816-8826.

Ferreira-Santos, P., Nunes, R., De Biasio, F., Spigno, G., Gorgoglione, D., Teixeira, J. A., et al. (2020). Influence of thermal and electrical effects of ohmic heating on C phycocyanin properties and biocompounds recovery from Spirulina Platensis. $L W T$. Food.Science and Technology, Article 109491.

Ferreira-Santos, P., Zanuso, E., Genisheva, Z., Rocha, C. M. R., \& Teixeira, J. A. (2020). Green and sustainable valorization of bioactive phenolic compounds from pinus byproducts. Molecules, 25(12). https://doi.org/10.3390/molecules25122931

Fikri, A. M., Popova, M., Sulaeman, A., \& Bankova, V. (2020). Stingless bees and mangifera indica: A close relationship? Indian Journal of Natural Products and Resources (IJNPR) [Formerly Natural Product Radiance (NPR)], 11(2), 130-134.

Filippini, T., Violi, F., D'Amico, R., \& Vinceti, M. (2017). The effect of potassium supplementation on blood pressure in hypertensive subjects: A systematic review and meta-analysis. International Journal of Cardiology, 230, 127-135.

Gargouri, W., Osés, S. M., Fernández-Muiño, M. A., Sancho, M. T., \& Kechaou, N. (2019). Evaluation of bioactive compounds and biological activities of Tunisian propolis. LWT - Food.Science and Technology, 111, 328-336.
Gupta, U., \& Gupta, S. (2014). Sources and deficiency diseases of mineral nutrients in human health and nutrition: A review. Pedosphere, 24(1), 13-38.

Gupta, A., Singh, A. K., Kumar, R., Jamieson, S., Pandey, A. K., \& Bishayee, A. (2021) Neuroprotective potential of ellagic acid: A critical review. Advances in Nutrition.

Ibrahim, N., Zakaria, A. J., Zhari Ismail, Y. A., \& Mohd, K. S. (2018). Application of GCMS and FTIR fingerprinting in discriminating two species of Malaysian stingless bees propolis. International Journal of Engineering \& Technology, 7(4.43), 106-112.

Kirkland, A. E., Sarlo, G. L., \& Holton, K. F. (2018). The role of magnesium in neurological disorders. Nutrients, 10(6), 730

Krell, R. (1996). Value-added products from beekeeping. Food \& Agriculture Org.

Laaroussi, H., Bouddine, T., Bakour, M., Ousaaid, D., \& Lyoussi, B. (2020). Physicochemical properties, mineral content, antioxidant activities, and microbiological quality of bupleurum spinosum gouan honey from the middle atlas in Morocco. Journal of Food Quality, 2020.

Li, Q., Wei, L., Lin, S., Chen, Y., Lin, J., \& Peng, J. (2019). Synergistic effect of kaempferol and 5-fluorouracil on the growth of colorectal cancer cells by regulating the PI3K/ Akt signaling pathway. Molecular Medicine Reports, 20(1), 728-734.

Martinez-Gonzalez, A. I., Díaz-Sánchez, Á., De La Rosa, L., Bustos-Jaimes, I., \& AlvarezParrilla, E. (2019). Inhibition of $\alpha$-amylase by flavonoids: Structure activity relationship (SAR). Spectrochimica Acta Part A: Molecular and Biomolecular Spectroscopy, 206, 437-447.

Miguel, M. da G., Doughmi, O., Aazza, S., Antunes, D., \& Lyoussi, B. (2014). Antioxidant, anti-inflammatory and acetylcholinesterase inhibitory activities of propolis from different regions of Morocco. Food Science and Biotechnology, 23(1), 313-322. https://doi.org/10.1007/s10068-014-0044-1

Milojković Opsenica, D., Ristivojević, P., Trifković, J., Vovk, I., Lušić, D., \& Tešić, Ž. (2016). TLC fingerprinting and pattern recognition methods in the assessment of authenticity of poplar-type propolis. Journal of Chromatographic Science, 54(7), 1077-1083.

Mouhoubi-Tafinine, Z., Ouchemoukh, S., \& Tamendjari, A. (2016). Antioxydant activity of some algerian honey and propolis. Industrial Crops and Products, 88, 85-90. https://doi.org/10.1016/j.indcrop.2016.02.033

Murai, A., Iwamura, K., Takada, M., Ogawa, K., Usui, T., \& Okumura, J. (2002). Control of postprandial hyperglycaemia by galactosyl maltobionolactone and its novel antiamylase effect in mice. Life Sciences, 71(12), 1405-1415.

do Nascimento, T. G., dos Santos Arruda, R. E., da Cruz Almeida, E. T., dos Santos Oliveira, J. M., Basílio-Júnior, I. D., de Moraes Porto, I. C. C., et al. (2019). Comprehensive multivariate correlations between climatic effect, metabolite-profile, antioxidant capacity and antibacterial activity of Brazilian red propolis metabolites during seasonal study. Scientific Reports, 9(1), 1-16.

Pasupuleti, V. R., Sammugam, L., Ramesh, N., \& Gan, S. H. (2017). Honey, propolis, and royal jelly: A comprehensive review of their biological actions and health benefits. Oxidative Medicine and Cellular Longevity. 2017.

Perugini, M., Manera, M., Grotta, L., Abete, M. C., Tarasco, R., \& Amorena, M. (2011). Heavy metal $(\mathrm{Hg}, \mathrm{Cr}, \mathrm{Cd}$, and $\mathrm{Pb}$ ) contamination in urban areas and wildlife reserves: Honeybees as bioindicators. Biological Trace Element Research, 140(2), 170-176.

Pobiega, K., Kraśniewska, K., \& Gniewosz, M. (2019). Application of propolis in antimicrobial and antioxidative protection of food quality-A review. Trends in Food Science \& Technology, 83, 53-62.

Popova, M., Bankova, V., Butovska, D., Petkov, V., Nikolova-Damyanova, B., Sabatini, A. G., et al. (2004). Validated methods for the quantification of biologically active constituents of poplar-type propolis. Phytochemical Analysis: An International Journal of Plant Chemical and Biochemical Techniques, 15(4), 235-240.

Rafińska, K., Pomastowski, P., Rudnicka, J., Krakowska, A., Maruśka, A., Narkute, M., et al. (2019). Effect of solvent and extraction technique on composition and biological activity of Lepidium sativum extracts. Food Chemistry, 289, 16-25.

Regnier, L., Salatino, A., \& Luiza, M. (2020). In , Vol. 8. Production of propolis and geopropolis by stingless bees (pp. 1-3). https://doi.org/10.15406/ mojfpt.2020.08.00234

Ristivojević, P., Stević, T., Starović, M., Pavlović, S., Özcan, M. M., Berić, T., et al. (2020). Phenolic composition and biological activities of geographically different type of propolis and black cottonwood resins against oral streptococci, vaginal microbiota and phytopathogenic Fusarium species. Journal of Applied Microbiology.

Sawaya, A. C. H. F., da Silva Cunha, I. B., \& Marcucci, M. C. (2011). Analytical methods applied to diverse types of Brazilian propolis. Chemistry Central Journal, 5(1), 1-10.

Serra Bonvehí, J., \& Orantes-Bermej, F. J. (2013). Element content of propolis collected from different areas of South Spain. Environmental Monitoring and Assessment, 185(7), 6035-6047.

Shakeri, A., Zirak, M. R., \& Sahebkar, A. (2018). Ellagic acid: A logical lead for drug development? Current Pharmaceutical Design, 24(2), 106-122.

Shehata, M. G., Ahmad, F. T., Badr, A. N., Masry, S. H., \& El-Sohaimy, S. A. (2020). Chemical analysis, antioxidant, cytotoxic and antimicrobial properties of propolis from different geographic regions. Annals of Agricultural Science.

Silici, S., Ünlü, M., \& Vardar-Ünlü, G. (2007). Antibacterial activity and phytochemical evidence for the plant origin of Turkish propolis from different regions. World Journal of Microbiology and Biotechnology, 23(12), 1797-1803.

Singh, S., \& Singh, R. P. (2008). In vitro methods of assay of antioxidants: An overview. Food Reviews International, 24(4), 392-415. https://doi.org/10.1080/ 87559120802304269

Socha, R., Gałkowska, D., Bugaj, M., \& Juszczak, L. (2015). Phenolic composition and antioxidant activity of propolis from various regions of Poland. Natural Product Research, 29(5), 416-422.

Socrates, G. (2001). Infrared and Raman characteristic group frequencies: Tables and charts. West Sussex: Wiley. 
Souza, E., Zaluski, R., Veiga, N., \& Orsi, R. (2016). Effects of seasonal variations and collection methods on the mineral composition of propolis from Apis mellifera Linnaeus Beehives. Brazilian Journal of Biology, 76(2), 396-401.

Subramanian, R., Asmawi, M. Z., \& Sadikun, A. (2008). In vitro alpha-glucosidase and alpha-amylase enzyme inhibitory effects of Andrographis paniculata extract and andrographolide. Acta Biochimica Polonica, 55(2), 391-398.

Svečnjak, L., Chesson, L. A., Gallina, A., Maia, M., Martinello, M., Mutinelli, F., et al. (2019). Standard methods for Apis mellifera beeswax research. Journal of Apicultura Research, 58(2), 1-108.

Svečnjak, L., Marijanović, Z., Okińczyc, P., Marek Kuś, P., \& Jerković, I. (2020). Mediterranean propolis from the Adriatic Sea islands as a source of natural antioxidants: Comprehensive chemical biodiversity determined by GC-MS, FTIRATR, UHPLC-DAD-QqTOF-MS, DPPH and FRAP assay. Antioxidants, 9(4), 337.

Teixeira, E. W., Negri, G., Salatino, A., \& Stringheta, P. C. (2010). Seasonal variation, chemical composition and antioxidant activity of Brazilian propolis samples. Evidence-based Complementary and Alternative Medicine, 7(3), 307-315.

Touzani, S., Al-Waili, N., El Menyiy, N., Filipic, B., Pereyra, A., Arabi, I. E., et al. (2018). Chemical analysis and antioxidant content of various propolis samples collected from different regions and their impact on antimicrobial activities. Asian Pacific Journal of Tropical Medicine, 11(7), 436.

Udensi, U. K., \& Tchounwou, P. B. (2017). Potassium homeostasis, oxidative stress, and human disease. International Journal of Clinical and Experimental Pathology, 4(3), 111.

Valencia, D., Alday, E., Robles-Zepeda, R., Garibay-Escobar, A., Galvez-Ruiz, J. C., SalasReyes, M., et al. (2012). Seasonal effect on chemical composition and biological activities of Sonoran propolis. Food Chemistry, 131(2), 645-651.
Williams, S. (1984). Official methods of analysis of the Association of official analytical chemists. In Arlington (Va.) : Association of official analytical chemists http://lib.ugent. be/catalog/rug01:000071630.

Wimalawansa, S. J., Razzaque, M. S., \& Al-Daghri, N. M. (2018). Calcium and vitamin D in human health: Hype or real? The Journal of Steroid Biochemistry and Molecular Biology, 180, 4-14.

Woisky, R. G., \& Salatino, A. (1998). Analysis of propolis: Some parameters and procedures for chemical quality control. Journal of Apicultural Research, 37(2), 99-105. https://doi.org/10.1080/00218839.1998.11100961

Wu, Y.-W., Sun, S.-Q., Zhao, J., Li, Y., \& Zhou, Q. (2008). Rapid discrimination of extracts of Chinese propolis and poplar buds by FT-IR and 2D IR correlation spectroscopy. Journal of Molecular Structure, 883, 48-54.

Xu, X., Pu, R., Li, Y., Wu, Z., Li, C., Miao, X., et al. (2019). Chemical compositions of propolis from China and the United States and their antimicrobial activities against penicillium notatum. Molecules, 24(19), 3576.

Yang, H., Dong, Y., Du, H., Shi, H., Peng, Y., \& Li, X. (2011). Antioxidant compounds from propolis collected in Anhui, China. Molecules, 16(4), 3444-3455.

Zhang, W., Cai, Y., Chen, X., Ji, T., \& Sun, L. (2020). Optimized extraction based on the terpenoids of Heterotrigona itama propolis and their antioxidative and antiinflammatory activities. Journal of Food Biochemistry, 44(8), Article e13296.

Zhang, H., Yang, Y., \& Zhou, Z. (2018). Phenolic and flavonoid contents of Mandarin (Citrus reticulata Blanco) fruit tissues and their antioxidant capacity as evaluated by DPPH and ABTS methods. Journal of Integrative Agriculture, 17(1), 256-263.

Zoffoli, H. J. O., do Amaral-Sobrinho, N. M. B., Zonta, E., Luisi, M. V., Marcon, G., \& Tolón-Becerra, A. (2013). Inputs of heavy metals due to agrochemical use in tobacco fields in Brazil's Southern Region. Environmental Monitoring and Assessment, 185(3), 2423-2437. https://doi.org/10.1007/s10661-012-2721-y 